\title{
Rainfall infiltration and soil hydrological characteristics below ancient forest, planted forest, and grassland in a temperate northern climate.
}

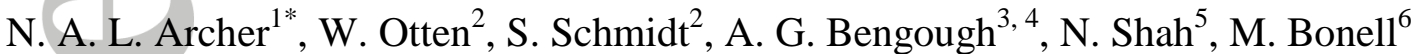

${ }^{1}$ British Geological Survey, Murchison House, West Mains Road, Edinburgh EH9 3LA, Scotland, UK

${ }^{2}$ SIMBIOS Centre, Level 5, Kydd Building, Abertay University, Bell Street, Dundee, DD1 1HG, Scotland, UK

${ }^{3}$ James Hutton Institute, Invergowrie, Dundee, DD2 5DA, Scotland, UK

${ }^{4}$ Division of Civil Engineering, University of Dundee, Dundee DD1 4HN, Scotland, UK ${ }^{5}$ Forest Research, Northern Research Station, Roslin, Midlothian EH25 9SY, Scotland, UK ${ }^{6}$ UNESCO Centre, University of Dundee, Perth Road, Dundee DD1 4HN, Scotland, UK

*Corresponding author email: nicarc@bgs.ac.uk

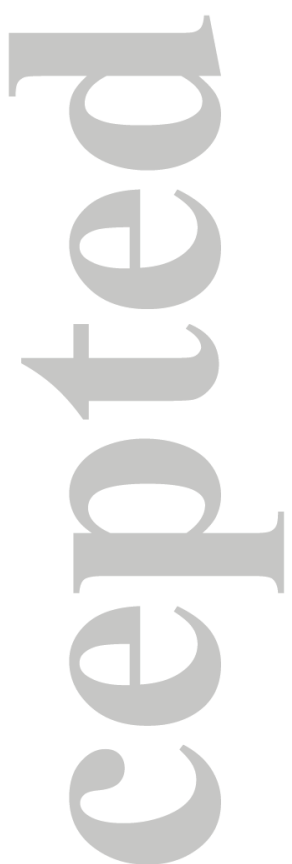

This is the peer reviewed version of the following article:

Archer, N.A.L., et al. 2015. Rainfall infiltration and soil hydrological characteristics below ancient forest, planted forest, and grassland in a temperate northern climate. Ecohydrology. doi: $10.1002 /$ eco. 1658

which has been published in final form at http://dx.doi.org/10.1002/eco.1658. This article may be used for non-commercial purposes in accordance with Wiley Terms and Conditions for Self-Archiving. 


\section{ABSTRACT}

How rainfall infiltration rate and soil hydrological characteristics develop over time under forests of different ages in temperate regions is poorly understood. In this study, infiltration rate and soil hydrological characteristics were investigated under forests of different ages and under grassland. Soil hydraulic characteristics were measured at different scales under a 250 year old grazed grassland (GL), a six (6yr) and 48 (48yr) year old Scots pine (Pinus sylvestris) plantation, remnant 300 year old individual Scots pines (OT) and a 4000 year old Caledonian Forest (AF). In-situ field saturated hydraulic conductivity (Kfs) was measured and visible root:soil area was estimated from soil pits. Macroporosity, pore structure, and macropore connectivity were estimated from X-ray tomography of soil cores, and from water-release characteristics.

At all scales the median values for $K_{f s}$, root fraction, macro-porosity and connectivity values tended to $\mathrm{AF}>\mathrm{OT}>48 \mathrm{yr}>\mathrm{GL}>6 \mathrm{yr}$, indicating that infiltration rates and water storage increased with forest age. The remnant Caledonian Forest had a huge range of $K_{f s}$ (12 to > $4922 \mathrm{~mm} \mathrm{~h}$-1), with maximum $K_{f s}$ values 7 to 15 times larger than 48 -year-old Scots pine plantation, suggesting that undisturbed old forests, with high rainfall and minimal evapotranspiration in winter, may act as important areas for water storage and sinks for storm rainfall to infiltrate and transport to deeper soil layers via preferential flow. The importance of the development of soil hydrological characteristics under different aged forests is discussed.

Keywords: hydraulic conductivity, forest age, macroporosity, old forest, soil water retention

\section{INTRODUCTION}

Infiltration rate is often enhanced by the presence of vegetation and parent material (Cerda, 1999). This is well documented particularly in arid ecosystems where vegetation mosaics have distinct zones of run-off in bare less permeable areas. The run-off water is then obstructed by vegetation patches and infiltrates into the more permeable soils in the vegetated patches. Such vegetation mosaics redistribute the limited water to accumulate within vegetated patches (Bromley et al. 1996; Aguiar and Sala, 1999; Dunkerley, 2002; Ludwig et al., 2005, Archer et al., 2012). In humid temperate environments, intense rainfall events are more likely to bypass the layer of vegetative cover (Llorens et al., 1997) to reach the soil surface where the water will either infiltrate the soil or runoff; the use of vegetation to 
enhance rainfall infiltration has become recognised as a cheaper, more natural alternative to engineered structural defences to reduce problems of flooding in such humid temperate environments. Afforestation can be used as a component of natural flood management to reduce and slow down overland flows and decrease maximum discharge rates into rivers (Calder et al., 2003). Infiltration rates are generally high under trees and have been shown to be up to 60 times greater under woodland shelter belts than grazed pasture (Carroll et al., 2004) with runoff volumes reduced by $78 \%$ under trees (Marshall et al., 2014). Morevoer, forests have greater evapotranspiration rates than other types of vegetation including grassland (Zhang et al., 2001), and this greater water use can lead to drier soils and a higher soil moisture deficit during the growing season, resulting in additional soil water storage (Nisbet et. al., 2011; Thomas and Nisbet, 2006). Arid and semi-arid environments, therefore, have great potential to dry the soil profile and increase the soil storage capacity for newly infiltrating water (Newman et al., 2006). In temperate climates, however, rainfall often exceeds evapotranspiration during winter. Understanding the effects of afforestation, therefore, is important if we want to better understand the ecohydrological processes involved and manage land sustainably and in harmony with the hydrological cycle.

Infiltration rate depends on the soil hydraulic conductivity, rainfall intensity and the initial soil moisture content. Vegetation modifies the soil matrix in a number of ways that affects soil hydraulic conductivity and soil water storage. Roots alter the distribution of pore size and connectivity between pores and as they push into the soil matrix they release complex organic compounds into the soil (Bengough, 2012). The continuous network of branched roots that permeate the soil, with new roots frequently forming while old ones decay, cause hydrological processes to change. Root length distribution has a major effect on infiltration, increasing preferential flow pathways within the rooting zone (Lange et al., 2009). Turnover rates of very fine roots can vary from a period of days and years for thick structural roots of trees (Eissenstat et al., 2000), generating continuous flow pathways through the soil. These pathways are also lined with organic remains of root material and associated microbial populations, which maintain the structure of these cavities (Jassogne et al., 2007). The combination of soil bacteria, fungal populations and organic deposits are also likely to influence the rate of wetting in the rhizosphere soil (Bengough, 2012). Ahuja et al., (2010), showed that there is a power-law relationship between saturated hydraulic conductivity and the "effective porosity" (saturated water content minus water content at $-33 \mathrm{kPa}$ ). Bengough (2012), points out that "the equivalent pore diameter corresponding to a suction of- $33 \mathrm{kPa}$ is 
approximately $10 \mu \mathrm{m}$ - the diameter of a root hair." Saturated flow therefore depends strongly on connected pore spaces which have dimensions of plant roots (Bengough, 2012). In effect, root systems create a complex interconnected drainage system, partitioning and transporting water resources within catchments.

Increasing rainfall infiltration into the soil profile through tree-planting is in many ways a natural "drainage system", analogous to that of engineered drainage. However, the ways in which these two approaches maintain the capacity to regulate water flow within landscapes over time are driven by different mechanisms. Artificial drainage, once implemented, has an instant effect on diverting water flow but if not maintained by physical removal of soil and vegetation over time, this capacity decreases (Hansen, et al. 1979, p. 307). The positive benefits of tree plantations on soil infiltration are well documented ( Ilstedt et al., 2007; Taylor et al. 2008; Osuji et al., 2010; Archer et al., 2013; Jarvis et al., 2013; Marshall, et al. 2014), but the maintenance and enhancement of soil infiltration by vegetation over time are driven by complex ecohydrological processes that are often uncertain in terms of precise mechanisms of vegetation-soil-water interactions (e.g. Rodriguez-Iturbe, 2000; Nuttle, 2002; Schwinning, 2010; King and Caylor 2011; Calder, 2005; Asbjornsen et al., 2011). There is a need to better characterise the vegetation-soil-water interactions that underlie afforestation and other land uses (Ilstedt et al., 2007). Studies that have investigated enhanced infiltrability through ecohydrological processes have predominantly been conducted in arid and semi-arid regions (e.g. Bromley et al. 1996; Dunkerley, 2000; Zou et al., 2013; Rodriguez-Iturbe et al., 2007), rather than in wet temperate regions.

The few investigations of infiltration rates in relation to forest age, have observed that older forests generally have higher infiltration rates (Marshall et al., 1014; Archer, et al,. 2013; Hümann et al. 2011; Leiva, et al., 2009; Deuchars et al., 2006). There are exceptions, however, where forests can decrease infiltration rates (Ghimire et al., 2013) and result in hydrophobic soil characteristics (Bens et al., 2007). The correlation between vegetation biomass and infiltration capacity may depend on climate, being greater in semi-arid regions than in more humid ones (Thompson, 2010). For example, in wet northern latitudes with less seasonality in precipitation, soil type has greater influence on run-off than vegetation per se (Geris et al., 2015).

The main aim of this paper is to investigate the effects of forest age in a northern temperate environment on soil hydrological characteristics and on rainfall infiltration during intense 
rainfall events. The study was undertaken in Scots pine (Pinus sylvestris) forests of different ages (a baseline 4000-year-old Caledonian Forest); six and 45-year-old Scots pine plantations, remnant 300-year-old individual Scots pine trees and under grassland, in the north of Scotland; an area typical of northern wet climate with limited seasonal variation in precipitation.

\section{SITE DESCRIPTION}

The study area is situated in the Cairngorm Mountains (Fig 1a), which is the largest continuous area of high ground above 1,000 $\mathrm{m}$ in the United Kingdom and receives some of the highest average annual precipitation $(1,440 \mathrm{~mm})$ and estimated annual runoff $(1,040 \mathrm{~mm})$ in Europe (Marsh and Anderson, 2002). Precipitation in the Cairngorms is spatially variable; annual precipitation often exceeds 2,250 $\mathrm{mm}$ on the summits, and decreases to less than 900 $\mathrm{mm}$ on the eastern side of the Cairngorms (Ellis and McGowan, 2006, p. 354), where the mountains create a 'rain shadow' to the wetter oceanic climate on the west coast. Cool temperatures and high precipitation cause rainfall to exceed potential evapotranspiration for most of the year (Birse and Dry, 1970), particularly at high altitudes.

Five areas were chosen (Fig 1b) within the Inshriach Forest area managed by the Forestry Commission (the government department responsible for forestry in England and Scotland) area and the Glen Feshie estate, (a private run estate) situated in the Feshie Valley. The sites were chosen to represent different aged Scots pine plantations, a grazed grassland and a remnant Caledonian Forest. The descriptions of each field site are the following:

1) The grassland site (GL) situated within the Glen Feshie Estate, has been managed for over two hundred years for grazing, and is presently grazed by cattle.

2) The six-year-old Scots pine plantation (6yr) was re-planted in 2006 on the site of a recently harvested Scots Pine plantation. The trees were planted on mounded sections, divided by excavated drains. There was much decaying wood from harvested trees on the ground and heather was present at this site.

3) The 48-year-old Scots pine plantation ( $48 \mathrm{yr}$ ) was planted in 1964. Prior to planting the site is described as Vaccinium myrtillus with patches of Betulla spp. It was ploughed and planted with Scots pine and appears to have been fertilised with phosphorus, although there is no indication if this was over the entire site. 
4) The 'Old Trees' site (OT) is an area of 300 year old individual Scots pine trees, widely spaced with an understory of Calluna vulgaris - Juniperus communis ssp nana heath, and in more open areas Vaccinium myrtillus. Eight years ago, there was a Scots pine plantation planted around these old trees, which was felled, leaving the old trees and the area to recolonize naturally. The 6 and 48 year old plantations and the 'Old Tree' site are owned and managed by Forestry Commission Scotland (FCS).

5) The 'Ancient Forest' site (AF) is considered a surviving remnant of Ancient Caledonian pinewood (Pinus sylvestris var. scotica), surviving in the steep middle slopes to around $650 \mathrm{~m}$. They are considered to be directly descended from the pines that colonised Scotland following the ice-age around 7,000 BC (Steven and Carlisle, 1959). It is a Special Area of Conversation (a site designated under the Habitats directive) and is owned and managed in partnership by Scottish Natural Heritage (the Scottish public body responsible for the country's natural heritage) and FCS. Unlike sites 6yr and 48yr, this area has an extensive understory of Vaccinium myrtillus, Calluna vulgaris and Sphagnum species that often cover granitic boulders. Sampling in this area took place above the Allt Ruadh (Red Burn).

The main soil type in all areas is humus podzols (Bruneau, 2006, p.45), overlying hummocky glacial deposits (sites 6yr, $48 \mathrm{yr}$ and OT), and humus-iron podzols overlying glacio-fluvial deposits (site GL), as shown in Fig 1b. The soils in the AF site were humus podzols and although there is no superficial geology shown at this location in Fig. 1b, the bottom of the Allt Ruadha, had alluvial deposits. Site characteristics (landuse, soils, superficial geology and bedrock) are summarised in Table 1, with photos of each site area and shallow soil profiles (depth $0.3 \mathrm{~m}$ ) describing the depth of organic material and presence of roots (Fig. 2).

\section{METHODODOLOGY}

To understand the soil hydrological properties at each site location we used a combination of in-situ field measurements and laboratory measurements of soil cores taken from each site location. Each method measured at different scales. In-situ field saturated hydraulic conductivity $\left(K_{f s}\right)$ measurements were therefore taken in the field, using a constant head well permeameter (CHWP). The saturated wetting front measured by the CHWP theoretically extends to infinity as described by Elrick et al. (1989), although, in reality the field-saturated sphere is finite. This is because the actual wetted zone of the field-saturated area under natural environmental field conditions depends on soil porosity and the volume of water 
infiltrated into the soil. Considering the volume of water used in each location in the $K_{f s}$ measurements and total porosity estimated from the soil cores taken from each location, the average sphere of wetted area was $524 \mathrm{~cm}^{3}$ (equivalent to a sphere, diameter $10 \mathrm{~cm}$ ).

Extracted soil cores from each site location were used to measure soil water retention characteristics, using a combination of ceramic plates and pressure chambers. This method typically assesses porosity in samples with typical diameters of centimetres and relates to the release of soil water under different matric potentials (suctions). X-ray Computer Tomography (CT), also using soil cores taken from the site locations was used to determine pore networks and their connectivity at $\mu \mathrm{m}$ resolution on small samples. In this study, the samples measured for water-release characteristics and by X-ray tomography had volumes $98.5 \mathrm{~cm}^{3}$ and $2 \mathrm{~cm}^{3}$ respectively. These techniques quantify different complementary hydrological characteristics, but few studies have recorded measurements at this range of scales in forest soils.

\section{Field methodology}

\section{In-situ field hydraulic conductivity measurements}

Field-saturated hydraulic conductivity $\left(K_{f s}\right)$ was estimated for six locations (two auger holes at each location; soil depths 0.04 to $0.15 \mathrm{~m}$, and 0.15 to $0.25 \mathrm{~m}$ ) at each field site using a constant head well permeameter (CHWP; Talsma and Hallam, 1980). The Glover solution, with a correction for the effect of gravity (Reynolds et al., 1983), was used to estimate $K_{f s}$ (Archer et al, 2014).

The $K_{f s}$ of the upper soil layer was measured at depths from 0.04 to $0.15 \mathrm{~m}$ giving a head $(H)$ of $0.11 \mathrm{~m}$, to ensure that surface flow did not interfere with lateral and vertical flow occurring within the hole. The lower soil layer was augered to $0.25 \mathrm{~m}$ depth, and the constant falling head level re-adjusted to $0.15 \mathrm{~m}$, to measure the lower soil depth ( 0.15 to $0.25 \mathrm{~m})$, giving an $H$ of $0.10 \mathrm{~m}$. The maximum depth of $K_{f s}$ measurements was $0.25 \mathrm{~m}$ as, on some sites, rocks and gravel prevented deeper augering and at all times the water table depth was below $0.6 \mathrm{~m}$. To obtain a representative sample for each field site, three locations were measured near to the base of trees and three locations were measured between trees. In the grassland, locations were measured randomly within the field, at least 10 metres apart, to ensure that the measured $K_{f s}$ were spatially independent (Zimmermann and Elsenbeer, 2008; Sobieraj et al., 2004). 
A $0.06 \mathrm{~m}$ diameter auger was used throughout the investigation (auger hole radius, $a$, between 0.0325 and $0.035 \mathrm{~m}$, giving an $H / a$ value of approximately 3 ). An $H / a$ ratio of 3 or above is important for stable measurements (Archer et al., 2014) A nylon brush was used to gently brush the auger hole walls to reduce smearing, with a pre-wetting phase of $20 \mathrm{~min}$ to ensure saturation (Archer et al., 2014) and shorten the time to reach steady state flow (Talsma and Hallam, 1980). .

\section{Excavation of soil cores and in-situ root descriptions}

Three soil pits (two near the base of trees and the third pit, between trees), were excavated at each site to sample two soil cores $(5.6 \mathrm{~cm}$ diameter $\mathrm{x} 4.0 \mathrm{~cm}$ height $)$ from each of three soil layers: 0.06 to $0.10 \mathrm{~m}, 0.16$ to $0.20 \mathrm{~m}$ and 0.26 to $0.40 \mathrm{~m}$. Half of the cores were analysed using X-ray tomography to estimate pore connectivity and the other half were analysed to determine water retention curves (i.e. total of three replicates per depth from each field site for water-release, and three for X-ray tomography, x 3 depths x 5 field sites).

After removing the soil cores, the pit was dug to $0.4 \mathrm{~m}$ depth $\mathrm{x} 0.35 \mathrm{~m}$ wide, and the pit wall slightly roughened to expose fine roots. An acetate sheet was placed on the wall and a fine marker pen used to dot any clearly defined roots $(\geq 1 \mathrm{~mm}$ diameter, as described by Bohm 1979 , p. 55). Thicker roots ( $>2 \mathrm{~mm}$ ) were marked with a thicker pen, and the outlines of even larger root diameters delineated. No distinction was made between alive and dead roots. Stones buried in the profile were shaded and changes in soil horizons were marked and described. The proportional areas of roots, soil matrix, and stones, were estimated for each acetate sheet $\left(0.3 \mathrm{~m} \times 0.35 \mathrm{~m}\right.$ depth, total area $\left.1050 \mathrm{~cm}^{2}\right)$ and root numbers and diameters were estimated for depth increments of $0.10 \mathrm{~m}$ on each acetate sheet.

\section{Laboratory characterisation of soil water release curves and organic matter content}

Soil cores were saturated with deionised water for 2 to 10 days and then equilibrated on ceramic tension tables at matric potentials $-0.5,-1,-2.5,-5,-10,-25$, and $-50 \mathrm{kPa}$ for periods of up to 7 days. Soil cores were then transferred to pressure plate chambers and equilibrated to $-100 \mathrm{kPa}$, and finally $-250 \mathrm{kPa}$. Soil core mass was measured after each equilibration and used to calculate volumetric water content, using the volume of the sample and taking account of shrinkage during drying. Shrinkage of core volumes was estimated by measuring the core volumes at matric potentials of $-10 \mathrm{kPa},-50 \mathrm{kPa},-100 \mathrm{kPa}$ and $-250 \mathrm{kPa}$. 
The stone $>2 \mathrm{~mm}$ content and the weight loss-on-ignition (at $600^{\circ} \mathrm{C}$ - sufficiently hot to burn off organic matter but not carbonate; Rowell, 1994) was measured at the end of the experiment. Capillary theory was used in relating matric potential to the radius of the pores to estimate an equivalent pore size distribution from the water release curve (Nimmo, 2004). Soil pore size was classified by their function following Cameron and Buchan, (2006, p. 1350), who describe drainable macropore size to be $>30 \mu \mathrm{m}$ (assumed to drain at $-10 \mathrm{kPa}$ ) and storage micropores (estimated as the volume of water draining between $-10 \mathrm{kPa}$ and $1500 \mathrm{kPa}$, at permanent wilting point).

\section{Characterisation of pore geometry at microscopic scales using X-ray tomography}

$\mathrm{X}$-ray CT was used to obtain microscopic 3D images of the internal pore geometry of undisturbed soil samples. For each site, 3 soil cores were selected from depths taken between 12 and $22 \mathrm{~cm}$ depth. 3D volumetric images of the internal pore geometry and soil structure were obtained using a Metris X-Tek HMX CT scanner (Nikon Metrology, Tring, Herts, UK). The system is equipped with a Varian Paxscan $2520 \mathrm{~V}$ detector, a $225 \mathrm{kV}$ X-ray source (Nikon Metrology X-Tek Systems Ltd, Tring, UK) and a focal spot of $5 \mu \mathrm{m}$. A molybdenum target was used with a $0.5 \mathrm{~mm}$ thick aluminium filter to reduce beam hardening. Metris software CT Pro v2.0 was used for reconstruction using a filtered back-projection algorithm (Nikon Metrology, Tring, Hets UK). The soil samples were scanned at $110 \mathrm{kV}$ and $96 \mu \mathrm{A}$ with 1750 projections. A resolution of $39 \mu \mathrm{m}$ was obtained.

\section{Image analysis of X-ray tomography}

Differences in soil structure were assessed by X-ray micro CT for selected samples from the mid profile soil cores ( 0.12 to $0.22 \mathrm{~m}$ depth). $2 \mathrm{D}$ cross sections (top view) from the $3 \mathrm{D}$ volumetric images of soil samples of different sizes were saved as image sequences (slice thickness $=$ voxel size) using the software VGStudio MAX v2.1 (Volume Graphics, Heidelberg, Germany). These Images were cropped to a size of $512 \times 512 \times 512$ voxels $(0.2$ $\times 0,2 \times 0.2 \mathrm{~cm})$, and pores were identified in the X-ray CT volumes by converting the cropped images into binary images: Thresholding values were determined by minimizing the intra-class variance given by the mean square error (MSE) between the greyscale and the corresponding binary image (Hapca et al., 2013) or by using Indicator Kriging (Houston et al., 2013). This first method included a pre-classification of the pore and solid populations in addition to the well-established Otsu's technique (Otsu, 1979, Hapca et al., 2013). The macro-porosity (pores $>39 \mu \mathrm{m}$ ) and pore connectivity were determined from the algorithm for pore volume estimation described in Ohser and Mücklich (2000). 


\section{Statistical analysis}

Hydraulic conductivity and root numbers were tested for normality using the AndersonDarling and Kolmogorov-Smirnov statistical tests. Values of $K_{f s}$ were not normally distributed and so were log-transformed (Bonell et al., 2010). Even when log transformed the variances differed significantly between sites using the Bartlett's test (test statistic $=24.98$, pvalue $=0.03$ ), and so the Kruskal-Wallis non-parametric test was used to test for significant $K_{f s}$ differences between the sites and soil depths. Two sample locations in the AF site gave $K_{f s}$ values beyond the capacity of the CHWP (maximum rate of measurement $4922 \mathrm{~mm} \mathrm{~h}^{-1}$ ), these measurement was removed from the statistical analysis, but noted and graphed in the results. The Kruskal-Wallis test was used to test significant differences between sites for organic matter and macroporosity as Bartlett's test showed that variances were unequal for both these characteristics (test statistic $=57.39$, p-value $<0.001$ and test statistic $=35.24$, pvalue $<0.001$ respectively).

The distributions of total root numbers in the three pits for all sites were not significantly different to a normal distribution, and the Bartlett's test showed that the variances between sites were similar (Test statistic $=7.89, \mathrm{p}$-value 0.096). Therefore a one-way ANOVA was used to test the null hypothesis that all sites had the same mean total root numbers. These data were further analysed using the Fisher Least Significant Difference test to group data with similar variances (Dytham, 1999).

\section{Rainfall intensity-duration-frequency analysis (IDF) and inferring dominant hydrological pathways during storms}

The vertical distribution of $K_{f s}$ and prevailing rainfall intensities are factors that determine the dominant stormflow pathways (as defined by Chappell et al., 2007) during and shortly after a rainfall event (Gilmour et al., 1987; Zieglar et al., 2006; Zimmermann and Elsenbeer, 2008;

Germer et al., 2010; Bonell et al., 2010; Hassler et al. 2011; Ghimire et al., 2013). Stormflow pathways include infiltration - vertical percolation, infiltration -excess (IOF, Horton, 1933) or saturation-excess overland flow (SOF), subsurface stormflow, SSF (Chorley, 1978) and were inferred (by selecting percentiles of maximum rainfall intensities $\left(\mathrm{I}_{\max }\right)$, which are then superimposed on measured datasets of $K_{f s}$ values.

In this study $I_{\max }$ for different rainfall durations for the field site were derived using the Flood Estimation Handbook (FEH) depth-duration-frequency (DDF) model on a $1 \mathrm{~km}$ grid, as 
described by Faulkner (1999), to fit rainfalls aggregated over 15 to 360 minute rainfall durations for 2, 10, 50 and 100 year return periods. Two sites were modelled to provide DDF curves: one at the GL site, which had slightly lower modelled rainfall and the other at the AF site which was located closer to mountains had higher rainfall (Fig.3). Because of the close proximity of sites 6yr, 48yr and OT to the GL site, it was considered that these sites would have the same DDF curves as the GL site.

The values modelled for DDF curves, 1 in 2, 10, 50 and 100 year return periods over a maximum intensity of 15 minutes $\left(\mathrm{I}_{15 \max }\right)$ were converted to rainfall intensity-durationfrequency (IDF) values. Possible canopy interception and storage of rainfall for sites 48yr, $\mathrm{OF}$ and AF were also taken into account by reducing the calculated $\mathrm{I}_{\max }$ values by $25 \%$ to $45 \%$ for these sites following a study in Britain which found that interception losses from conifer stands are typically 25-45\% (Calder et al, 2003). However, during high intensity rainfall, interception losses are unlikely to be as high, because interception decreases at higher rainfall intensities, as observed by Llorens et al., (1997) when investigating Pinus Sylvestris. The final values were superimposed on boxplots to illustrate the spread of $K_{f s}$ values for each measured site. The choice of $\mathrm{I}_{15 \max }$ of different return periods was to conceptualize how short-duration, high intensity storms may cause IOF and possibly SSF in relation to the range of measured $K_{f s}$ under different forest ages. As $K_{f s}$ was measured at several depths (soil surface, $0.04-0.15 \mathrm{~m}$ and $0.15-0.25 \mathrm{~m}$ ) at sites 1 and 4 , possible inference of subsurface stormflow (SSF) could also be considered at these sites, as described by Bonell (2005).

\section{RESULTS}

\section{Comparing data at different scales}

Fig. 4 shows a diagrammatic representation of the different scales of measured soil volumes by the CHWP, the pressure chamber technique and X-ray tomography.

Bringing the data together in the form of box plots shows the overall range and median values of data for different soil characteristics at different scales. There is a consistent pattern within all scales where the median values for $K_{f s}$ (Fig. 4A), profile root fraction, macro-porosity and connectivity (Fig. 4B) are all ordered as AF > OT > 48yr > GL > 6yr sites. The pattern is different for median total porosity, where $6 \mathrm{yr}>\mathrm{AF}>\mathrm{OT}>48 \mathrm{yr}>\mathrm{GL}$. To understand the data in more detail, each measurement technique and soil characteristic is considered in turn. 
The micro-scale: porosity and connectivity measured by X-ray tomography

Soil structures differed substantially between the sites (Fig. 5). Snapshots through the 3D volume data showed the spatial distribution of roots, particulate organic matter, pores and soil matrix, comprising a mixture of mineral soil, organic matter content, and micro-pores below the scanning resolution. Images from the $6 \mathrm{yr}$ old site, showed a largely structureless organic mass with occasional larger pores volumes and absence of soil aggregates or mineral particles. This is in contrast to the GL site which showed a greater degree of granular mineral particle structure. The soils under the older forests (48 yr old, OT and AF) had a greater diversity of structure, as the cores contained larger pore spaces, soil aggregates, and also contained organic material, such as root fragments and other organic compounds that have not fully decomposed.

For the mid soil layer $(0.12$ to $0.25 \mathrm{~m})$ the volume fraction of visible larger pores $(>39 \mu \mathrm{m})$ was lowest for the 6yr site (median 0.08) and highest for the AF site (0.18), but variation at this scale between samples was large (Fig. 4B) so the results were not significantly different $(\mathrm{p}=0.092)$. Median pore connectivity was relatively high for all sites (Fig. 4B; ranging from

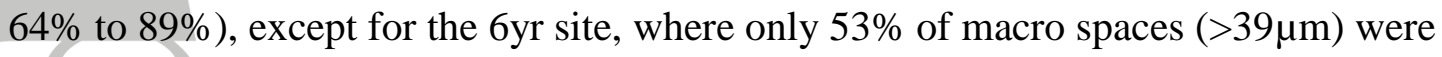
connected.

\section{Soil core scale: Soil Characterisation and water release curves}

Total porosity for all sites (shown as box plots in Fig 4B) was estimated from saturated soil cores, and ranged on average from 0.69 to 0.89 ; the 6yr site having greater total porosity than any other site. Total porosity was observed to be highly correlated with organic matter content $\left(\mathrm{R}^{2}=0.874\right.$, Fig. 6). Organic matter content was greatest in the upper soil layers, except for the 6yr site, which had significantly higher organic matter ( $>90 \%$, Table 2$)$ at all depths $(H=18.90, D F=4, p=0.001)$, as illustrated in Fig. 6. When soil volumes were compared between saturated soil volumes to soil volumes subjected to $-250 \mathrm{kPa}$, soil shrinkage was much greater for the 6yr site, where $34 \%$ to $46 \%$ of saturated soil volume was lost, unlike any of the other sites (Table 2). This is typical of organic soils (Schwärzel, et al, 2002) and because soil volume shrinkage was so high during consecutive increases of pressure, the 6yr site cores were removed for macropore size analysis using the water release curve technique. The water release curves are shown in the appendix (fig.11) to illustrate the overall data for sites GL, 48yr, OT and AF. Soil bulk density (Table 2) ranged from 0.11 to 0.71 which is much smaller than for most arable soils (typically 1.2 to $1.6 \mathrm{~g} \mathrm{~cm}^{3}$ ). 
Macropore volumes $(>30 \mu \mathrm{m})$ were significantly greater $(H=19.45, D F=4, p<0.001)$ at all soil depths for the AF site as shown in Fig. 4B (excluding the 6yr site). Macroporosity measured by the X-ray CT is for larger macropores $(>39 \mu \mathrm{m})$, than for the water release curves $(>30 \mu \mathrm{m})$, and so are not directly comparable.

The soil profile of the $6 y \mathrm{r}$ site had the highest median saturated water content ( $>90 \%$; Fig. 7) and the $\mathrm{AF}$ site had the greatest range of saturated water content (47 to $92 \%$ ) and held the least amount of water at the driest matric potential $(-250 \mathrm{kPa})$. The grassland and the 6yr site retained the greatest amount of water at $-250 \mathrm{kPa}$.

\section{Roots in the soil profile}

Total mean root numbers were significantly different $(F=3.99, D F=4, p$-value $=0.035)$ between the different sites for all depths. Mean root numbers did not differ between 6yr and GL sites (p-value >0.05), but root numbers in these sites were significantly different to AF, OT and 48yr sites ( $p$-value >0.05). The AF site had the largest average root area in the 1050 $\mathrm{cm}^{2} \mathrm{~m}$ profile face (Fig. 4B), than any other study area and had over twice the root area of the OT site, which has the second largest root area of all the study areas. Thick roots (diameter $>5 \mathrm{~mm}$ ) were present only in the 48yr, AF and OT sites (Fig. 8), whereas the GL and the 6yr sites were dominated by finer root diameters.

Roots at the OT and AF sites were often enmeshed inside rocks and along rock fissures and were associated with sandy material, which suggested that the local rock had enhanced weathering rates, or particle separation along rock fissures associated with the presence of roots.

\section{In-situ $K_{f s}$ between the study sites}

The $K_{f s}$ mean values between sites differed very significantly $(H=43.11, D F=4, p$-value < 0.001 ). The AF site had significantly greater $K_{f s}$ than all other sites (Fig. $4 \mathrm{~A}$ ), and was three orders of magnitude greater than the $K_{f s}$ measured in the 6yr site. The OT site had a lower median $K_{f s}$ than the $48 \mathrm{yr}$ site (Table 2), but the range of $K_{f s}$ was larger for the OT site (Table 2). Infiltration rates reflected the greater heterogeneity of the OT site in comparison with the $48 \mathrm{yr}$ site: $K_{f s}$ was larger under older individual trees in the OT site than in open areas away from old trees. Similar heterogeneity was found under Quercus robur in Yorkshire, U.K., using similar methodology (Chandler and Chappell, 2008). The smallest $K_{f s}$ was in the upper 
soil layer at the 6 year old Scots pine plantation (6yr). The GL and $6 \mathrm{yr}$ sites had similar $K_{f s}$ values that were significantly smaller at all depths in comparison with the other sites.

Two locations (one in the mid soil layer and another in the lower soil layer in a different location) in the AF site had extremely high $K_{f s}$ values, beyond the measurement range of the CHWP. Even after the period of pre-wetting was extended to one hour, it was not possible to ascertain that steady state infiltration had been achieved. These large values were retained in the dataset and are shown as outliers in the AF column in Fig. 4A. Upon examination of these locations in the field, relatively large cavities were identified, associated with plant roots.

Rainfall intensity-duration-frequency analysis (IDF) and inferring dominant hydrological pathways during storms

The $K_{f s}$ data was examined more closely by dividing the results measured at different soil depths (Fig. 9), here noted as mid and lower soil layers. $K_{f s}$ values at shallower depths (0.04 to $0.15 \mathrm{~m})$ were significantly greater than deeper soil depths $(0.15$ to $0.25 \mathrm{~m})(H=5.02, D F=$ $1, P 0.025)$.

The 1 in 10 year return periods over $I_{\max 15}$ considered to reach the soil surface, were modelled to be $42 \mathrm{~mm} \mathrm{~h}^{-1}$ for the GL, 6yr, $48 \mathrm{yr}$ and OT sites and $37.2 \mathrm{~mm} \mathrm{~h}^{-1}$ for the AF site. These values are superimposed as red lines on the box plot in Fig. 9. It is unlikely that there is a large amount of canopy interception during heavy rainfall as shown by Llorens et al. (1997), however to take into account a range of possible forest canopy interception percentages, 1 in 10 year $I_{\max 15}$ values were reduced by $25 \%$ and $45 \%$ to the forest plantation sites (6yr, $48 \mathrm{yr}$ and OT sites). A $25 \%$ and $45 \%$ reduction of IDF $\mathrm{I}_{\max 15}$ values for the $6 \mathrm{yr}$, 48yrand OT sites gave values $32 \mathrm{~mm} \mathrm{~h}^{-1}$ and $23 \mathrm{~mm} \mathrm{~h}^{-1}$ respectively and the AF site had reduced IDF $\mathrm{I}_{\max 15}$ from $28 \mathrm{~mm} \mathrm{~h}^{-1}$ and $21 \mathrm{~mm} \mathrm{~h}^{-1}$ repectively. These values are superimposed as short black and light blue lines in Fig. 9, where the lower light blue line is reduced by $45 \%$ and the upper black line is reduced by $25 \%$. If the box plots are below the line, then the storm rainfall is too intense for infiltration into the soil, such as is illustrated for both soil depth layers for GL and $6 y r$ sites. For sites 48yr and OT, the storm rainfall can enter the mid soil layer (0.04 -0.15 m), but the deeper less permeable layer would restrict percolation in most cases. AF is the only site where 1 in 10 year $I_{\max 15}$ storm rainfall can infiltrate into mid and lower soil layers. The mid soil layers under the 48yr and OT sites would allow high intensity rainfall to infiltrate, but the lower $\mathrm{K}_{f s}$ values in the deeper soil layers (Fig. 9), would impede percolation to deeper soil layers, indicating that subsurface stormflow would occur.

This article is protected by copyright. All rights reserved. 


\section{DISCUSSION}

\section{Effect of forest age and ecohydrological processes}

Older forests (AF, OT and $48 \mathrm{yr}$ sites) had greater $K_{f s}$ and higher medians of root to soil matrix fraction, macroporosity and macropore connectivity (Fig. 4). These trends corroborate the Lange et al. (2009) investigation and Bengough's review (2012) that saturated flow depends on root biomass increasing pore spaces and pore connectivity at all scales, ultimately generating larger hydraulic conductivity for water flow. The established AF site may have had time to develop diverse soil matrix containing macropores and organic material in varying states of decomposition (fig. 5), something that was not found in the GL site and was not so obvious in the $48 \mathrm{yr}$ site. This ensures a large range of saturated soil water contents (Fig. 7) and the ability to release water at low suctions (<-250 kPa), allowing water to be easily available for evapotranspiration. These results suggest that forest age is an important factor determining soil hydrological characteristics, and increasing infiltration rates, supporting other studies carried-out in northern temperate areas, which have also found that older established forests have higher infiltration rates than recently afforested areas (e.g., Hüman et al., 2011, Archer et al., 2013).

The significantly lower $K_{f s}$, macropore (>30 the 6yr site (fig. 4 and fig. 9), may be an indication of soil disturbance that took place six years previously when the plantation was felled; the dead wood was left to decay (increasing the organic matter content (fig. 4) and the ground was re-worked by heavy machinery to create drainage channels. The resulting amorphous organic structure of the 6yr old forest soil (Fig. 5), has lower macropore connectivity, which may explain the small $K_{f s}$ values at this site (Fig. 4 and 9). In the UK, guidance is available to prevent compaction and soil damage (Forestry Commission, 2011a; Forestry Commission 2011b), but more emphasis needs to be placed on improving techniques such as brash mat construction, maintenance and durability to preserve the macroporosity and drainage of the previously forested site; an Operations Practice Guide is currently being produced by the Forestry Commission to address some of these issues.

We have to recognise and understand the role of forests in the process of pedogenesis not only in terms of recent afforestation but also historical deforestation, which is common in many northern temperate countries. In parts of Europe and Scandinavia, coniferous plantations are a relatively "new" landuse, particularly since the 1940s when forestry was 
implemented as government policy to produce wood (Kuusela, 1994). The conifer plantations in this study can be regarded as typical of such a landuse change and it is therefore interesting to compare the data between the different sites. However, it is difficult to assess how longterm forest development affects infiltration rates and water storage as there are very few forested areas with comparable site conditions above 50 years old, mainly due to the deforestation of endemic forest in Europe; for example, anthropogenic forces reduced endemic forest cover in Scotland to only $4 \%$ by area in the eighteenth century (Armit and Ralston, 2003). The few remaining remnant endemic forests are therefore an extremely valuable resource to help us understand the possible ecohydrological processes that change and develop through time within a forest ecosystem in relationship to their surrounding abiotic environment.

The significant higher $K_{f s}$ in the $48 \mathrm{yr}$ site in comparison to the 6yr site also suggests that macroporosity and macropore connectivity may recover relatively quickly once a plantation is planted. However, very little is known about what happens to soil macroporosity and macropore connectivity during the approximate 50 year rotation of a forest plantation, i.e. when a forest is cut, planted and cut again. If plantations are planted to reduce flooding in high risk areas, further research is needed to understand below-ground processes of root growth/turnover in relationto the development of soil hydrological characteristics during forest plantation rotation.

\section{Below ground water flow}

The significant differences observed for $K_{f s}$ values between different depths and sites (Fig. 9 and Table 2) reflects the differences in soil pore volume, structure, and connectivity. The older mature forests (AF, OT and 48 yr old sites) allow infiltration of storm rainfall into the surface soil layers, unlike the grassland and young $6 \mathrm{yr}$ old pine plantation, corroborating evidence from other studies, such as Archer et al. (2013), Messing et al. (1997) and Taylor et al. (2008).

The rainfall IDF analysis indicates that the lower $K_{f s}$ values measured at the OT and 48yr old sites would allow high intensity rainfall $\left(23\right.$ to $\left.32 \mathrm{~mm} \mathrm{~h}^{-1}\right)$ to infiltrate only the mid soil layer (0.04 to $0.15 \mathrm{~m})$, but not the less impermeable lower soil depth $(0.15$ to $0.25 \mathrm{~m})$, inferring that at these two sites the less impermeable deeper layer would reduce percolation and may cause subsurface-storm flow that could rise to the ground surface as saturation-excess overland flow. The very small $K_{f s}$ values measured in the grazed grassland and 6 yr old sites infer that 
a 1 in 10 year $I_{\max 15}\left(42 \mathrm{~mm} \mathrm{~h}^{-1}\right.$ and 23 to $32 \mathrm{~mm} \mathrm{~h}^{-1}$ respectively) would not infiltrate these soils, and it is likely that ponding and infiltration excess overland flow would quickly develop at both these sites. The significantly higher $K_{f s}$ measured at mid and lower soil depths for the AF site (Fig. 4) infers that the undisturbed natural forest provides a better soil system to allow deeper percolation of high intensity rainfall.

Unlike semi-arid environments where research has been done to investigate groundwater recharge of deep rooted trees (Burgess, et al. 2001), temperate forests are often shallow rooted due to the presence ofimpermeable layers, or because the rooting systems avoid shallow water tables (Ray and Nicoll, 1998). The larger $\mathrm{K}_{\mathrm{fs}}$ values at deeper depths, as shown in the AF site, could cause rapid transfer of high intensity rainfall to shallow groundwater and produce a perched water table, if deeper soils layers are less permeable. Such relationships have been also suggested in studies of an established deciduous beech forest in the east of Germany (Schwärzel et al., 2012). However, further research is needed to understand such relationships.

\section{CONCLUSIONS}

The small number of sites sampled in this study provide a preliminary indication that older forests have greater $K_{f s}$ and higher medians of root to soil matrix fraction, greater proportion of macropores $(>30 \mu \mathrm{m})$ and higher macropore connectivity. This suggests that infiltration rates increased with forest age and that macroporosity, macropore connectivity and presence of roots are important for determining infiltration rates. The remnant Caledonian Forest had a huge range of $K_{f s}\left(12\right.$ to $\left.>4922 \mathrm{~mm} \mathrm{~h}^{-1}\right)$, with maximum $\mathrm{K}_{\mathrm{fs}}$ values 7 to 15 times larger than 48-year-old Scots pine plantation. This all indicates that undisturbed old forests in northern temperate environments, where rainfall is high and evapotranspiration is minimal during winter months, may act as important areas for water storage and as sinks for storm rainfall to infiltrate and transport to deeper soil layers via preferential flow. Previous felling, leaving dead wood to decay, ploughing, drainage installation and re-afforestation of the new plantation (6yr) may have increased organic matter, but reduced pore connectivity, causing very low $\mathrm{K}_{f s}$. However, even though the effects of harvesting plantations may impede infiltration rate, the significantly higher $K_{f s}$, macroporosity, root numbers and proportion of root area to soil matrix in the 48 year old plantation suggests that Scots pine plantations may recover root biomass relatively quickly, enhancing infiltration rates; this has important 
implications for ecohydrological processes and natural flood management in Europe given that conifer planting continues and a large number of conifer plantations are now mature.

To employ forest management for multiple benefits, including flood mitigation, requires better understanding of the time taken for afforested areas to develop the soil matrix and attain high infiltration rates with percolation of water to deeper soil layers. Coniferous plantations are a relatively new landuse, having mainly been established after the 1940s in Europe where few endemic undisturbed forests remain, and so it is difficult to predict how afforestation will influence water resources and pedogenisis in the long term. In this context, old undisturbed endemic forests are a valuable resource for understanding ecohydrological processes that develop during long periods of relative ecosystem stability in comparison to recently afforested areas associated with modern land use changes.

\section{Acknowledgements}

We thank Forestry Commission Scotland for access to Inshriach Forest, Scottish National Heritage for access to the Allt Ruadh Valley, the Glen Feshie Estate for access to their grazed grassland, and Roslyn Stevenson and Julian Manley for assistance in the field. We thank the Centre for Environmental Change and Human Resilience, University of Dundee, for funding, and M. Krol for technical assistance. The James Hutton Institute receives funding from the

\section{Scottish Government.}

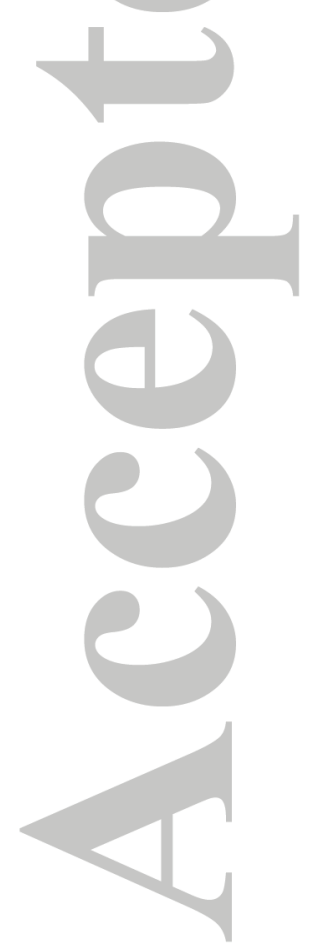

This article is protected by copyright. All rights reserved. 


\section{References:}

Aguiar and Sala. 1999. Patch structure, dynamics and implications for the functioning of arid ecosystems. Trends in Ecology and Evolution. 14, 7: 273-277.

Ahuja LR, Ma L, Green TR. 2010. Effective soil properties of heterogeneous areas for modeling infiltration and redistribution. Soil Science Society of America Journal 74:1469-1482. DOI:10.2136/sssaj2010.0073

Archer NAL, Quinton JN, Hess TM. Pathc vegetation and water redistribution above and below ground in south-east Spain. Ecohydrology, 5(1): 108-120.

Archer NAL, Bonell M, Coles N, MacDonald AM, Auton C, Stevenson R. 2013. Soil characteristics and landcover relationships on soil hydraulic conductivity at a hillslope scale: A view towards local flood management. Journal of Hydrology, 497: 208-222.

Archer NAL, Bonell M, MacDonald AM, Coles N. 2014. A constant head well permeameter formula comparison: its significance in the estimation of field saturated hydraulic conductivity in heterogeneous shallow soils. Hydrology Research. 25(6): 788-805. DOI:10.2166/nh.2014.159

Armit I, Ralston I. 2003. The coming of the Iron, 1000 BC to AD 500. In: People and Woods in Scotland, Smout TC (ed). Edinburgh University Press.

Asbjornsen H, Goldsmith GR, Alvarado-Barrientos MS, Rebel K, van Osch FP, Rietkerk M, Chen J, Gotsch S, Tobón C, Geissert DR, Gómez-Tagle A, Vache K, Dawson TE. 2011. Ecological advances and applications in plant-water relations research: a review. Journal of Plant Ecology 4: 3-22. DOI: 10.1093/jpe/rtr005

Bengough AG. 2012. Water dynamics of the root zone: rhizosphere biophysics and its control on soil hydrology: Vadoes Zone Journal, 11 (2) DOI: 10.2136/vzj2011.0111

Bens O, Wahl NA, Fischer H, Hüttl RF. 2007. Water infiltration and hydraulic conductivity in sandy cambisols: impacts of forest transformation on soil hydrological properties. European Journal of Forest Research. 126 (1): 101-109.

Birse EL, Dry FT. 1970. Assessment of climatic conditions in Scotland. 1. Based on Accumulated Temperature and Potnetial Water Deficit. The Macaulay Insitute for Soil Research: Aberdeen. 
Bohm W. 1979. Methods of studying root systems: Ecological studies volume 33. SpringerVerlag, Berlin, Germany. 188.

Bonell M. 2005. Runoff generation in tropical forests. In: Bonell M, Bruijnzeel LA (eds.), Forests Water and People in the Humid Tropics. International Hydrology Series. Cambridge University Press, Cambridge, UK. 314-406.

Bonell M, Purandara BK, Venkatesh B, Krishnaswamy J, Acharya HAK, Singh UV, Jayakumar R, Chappell N. 2010. The impact of forest use and reforestation on soil hydraulic conductivity in the Western Ghats of India: Implications for surface and sub-surface hydrology. Journal of Hydrology, 391 (1-2): 49-64.

Bromley J, Brouwer J, Barker AP, Gaze SR, Valentin C. 1997. The role of surface water redistribution in an area of patterned vegetation in a semiarid environment, south-west Niger. Journal of Hydrology. 198(4), 1-29. doi:10.1016/S0022-1694(96)03322-7

Bruneau, P. 2006. Geodiversity: Soils. In: Shaw P. and Thompson DBA (eds). The Naiture of the Cairngorms: Diversity in a changing environment. The Staionary Office. Edinburgh, UK. 42-51.

Burgess SO, Adams MA, Turner NC, White DA, Ong CK. 2001. Tree roots: conduits for deep recharge of soil water. Oecologia. 126: 158-165.

Calder IR, Reid I, Nisbet T, Green JC. 2003. Impact of lowland forests in England on water resources - application of the HYLUC model. Water Resources Research. 39: 13191328.

Calder IR. 2005. Blue Revolution - Integrated Land and Water Resources Management. Routledge: London, UK. pp. 374.

Cameron KC, Buchan GD. 2006. Porosity and Pore size distribution. In: Encyclopaedia of Soil Science, Volume 2, second edition, Lal, R. (ed.), CRC Press, 1350.

Carroll, Z.L., Bird, S.B., Emmett, B.A., Reynolds, B. and Sinclair, F.L. (2004). Investigating the impact of tree shelterbelts on agricultural soils. In: Landscape ecology of trees and forests. Edited by R. Smithers. International Association for Landscape Ecology (UK).

Chandler K, Chappell NA. 2008. Influence of individual oak (Quercus robur) trees on saturated hydraulic conductivity. Forest Ecology and Management, 256: 1222-1229. 
Chappell NA, Sherlock M, Bidin K, Macdonald R, Najman Y, Davies G. 2007. Runoff processes in southeast Asia: role of soil, regolith, and rock type. In: Swada H, Araki M, Chappell NA, LaFrankie JV, Shimizu A. (eds.), Forest Environments in the Mekong River Basin. Springer-Verlag, Tokyo, 3-23.

Chorley, R.J. 1978. Glossary of terms. In: Kirkby, M.J. (Ed.), Hillslope Hydrology. Wiley, Chichester, UK, pp. 365-375.

Deuchars SA, Townend J, Aitkenhead MJ, FitzPatrick EA. 2006. Changes in soil structure and hydraulic properties in regenerating rain forest. Soil Use Management. 15 (3): 183-187.

Dunkerley D. 2002. Systematic variation of soil infiltration rates within and between the components of the vegetation mosaic in an Australian desert landscape. Hydrological Processes. 16: 119-131. DOI: 10.1002/hyp.357.

Dytham C. 1999. Choosing and using statistics. London, Great Britain, Blackwell Science, $218 \mathrm{p}$.

Eissenstat DM, Wells CE, Yanai RD, Whitbeck JL. 2000. Building roots in a changing environment: implications for root longevity. New Phytologist. 147 (1): 33-42.

Elci A, Molz FJ. 2009. Identification of lateral macropore flow in a forested riparian wetland through numerical simulation of a subsurface tracer experiment. Water Air Soil Pollution. 197: 149-164. DOI:10.1007/s11270-008-9798-5

Ellis N, and McGowan G. 2006. Climate change. In: Shaw P. and Thoampson DBA (eds). The Nature of the Cairngorms: Diversity in a changing environment. The Stationary Office, Edinburgh, UK. 353-365.

Elrick DE, Reynolds WD, Tan KA. 1989. Hydraulic conductivity measurements in the unsaturated zone using improved well analyses. Ground Water Monitoring Review. 9: 184-193.

Elsenbeer H. 2001. Hydrologic flowpaths in tropical rainforest soilscapes - a review: Hydrological Processes. 15 (10): 1751-1759.

Faulkner D. 1999. Flood estimation handbook. Procedures for Flood Frequency Estimation. Rainfall Frequency Estimation, vol. 2. Institute of Hydrology, Wallingford, UK. 
Forestry Commission (2011a). Forests and Water. UK Forestry Standard Guidelines. Forestry Commission, Edinburgh. http://www.forestry.gov.uk/ukfs

Forestry Commission (2011b). Forests and Soil. UK Forestry Standard Guidelines.Forestry Commission, Edinburgh. http://www.forestry.gov.uk/ukfs

Forestry Commission. 2013a Forestry Statistics 2013.

Forestry Commission. 2013b The Scottish Forestry Strategy: Implementation Plan (2013-16) And Progress Report (2012-13). Forestry Commission Scotland

Geris J, Tetzlaff D, McDonnell J. Soulsby C. 2015. The relative role of soil types and tree cover on water storage and transmission in northern headwater catchments. Hydrological Processes. 29: 1844-1860.

Germer S, Neill C, Krusche AV, Elsenbeer H. 2010. Influence of land-use change on nearsurface hydrological processes: undisturbed forest to pasture. Journal of Hydrology. 380 (3-4): 473-480.

Ghimire CP, Bruijnzeel LA, Bonell M, Coles N, Lubczynski, MW, Gilmour DA. 2013. The effects of sustained forest use on hillslope soil hydraulic conductivity in the middle mountains of central Nepal. Ecohydrology, DOI: 10.1002/eco.1367 (11.02.13).

Gilmour DA, Bonell M, Cassells DS. 1987. The effects of forestation on soil hydraulic properties in the Middle Hills of Nepal: a preliminary assessment. Mountain Research Development. 7 (3): 239-249.

Hansen VE, Israelsen OW, Stringham GE. 1979. Irrigation principles and practices $4^{\text {th }}$ edition. John Wiley \& Sons Inc, Canada. 417 pages.

Hapca SM, Houston AN, Otten, W, Baveye, P. 2013. New objective segmentation method based on minimizing locally the intra-class variance of grayscale images. Vadoze zone, DOI:10.2136/vzj2012.0172.

Hassler SK, Zimmermann B, van Breugel M, Hall JS, Elsenbeer H. 2011. Recovery of saturated hydraulic conductivity under secondary succession on former pasture in the humid tropics. Forest Ecology Management 261 (10): 1634-1642.

Hillel D. 1980, Applications of Soil Physics. New York, Academic Press.

Horton RE. 1933. The role of infiltration in the hydrologic cycle. Transactions American Geophysical Union 14: 446-460.

This article is protected by copyright. All rights reserved. 
Houston A, Baveye P, Otten W, Hapca S. 2013. Image thresholding by adaptive window indicator kriging. Computers \& Geosciences 54: 239-248.

Hümann M, Schüler G, Müller C, Schüler R, Johst M, Caspari T. 2011. Identification of runoff processes - the impact of different forest types and soil properties on runoff formation and floods. Journal of Hydrology. 409 (3-4): 637-649.

Ilstedt U, Malmer A, Verbeeten E, Murdiyarson D. 2007. The effect of afforestation on water infiltration in the tropics: A systematic review and meta-analysis. Forest Ecology and Management. 251: 45-51.

Jarvis N, Koestel J, Messing I, Moeys J, Lindahl A. 2013, Influence of soil, land use and climatic factors on the hydraulic conductivity of soil: Hydrology and Earth System Sciences, 17: 10 .

Jassogne L, McNeill A, Chittleborough, D. 2007. 3D-visualization and analysis of macroand meso-porosity of the upper horizons of a sodic, texture-contrast soil: European Journal of Soil Science. 58 (3): 589-598.

King EG, Caylor KK. 2011. Ecohydrology in practice: strengths, conveniences, and oppertunities. Ecohydrology. 4: 608-612. DOI: 10.1002/eco.248.

Kuusela, K. 1994. Forest Resoruces in Europe. European Forest Institute. Research Report 1. Cambridge University, Cambridge, UK.

Lange B, Luescher P, Germann PF. 2009. Significance of tree roots for preferential infiltration in stagnic soils. Hydrology and Earth System Sciences. 13 (10): 18091821.

Llorens P, Poch R, Latron J, Gallart F. 1997. Rainfall interception by a Pinus Sylvestris forest patch overgrown in a Mediterranean mountainous abandoned area I. Monitoring design and results down to the event scale. Journal of Hydrology, 199: 331-345.

Ludwig A, Wilcox BP, Breshears DD, Tongway DJ, Imeson, AC. 2005. Vegetation patches and runoff-erosion as interacting ecological processes in semiarid lanadscapes. Ecology 86:288-297.

Marshall MR, Ballard CE, Frogbrook Z, Solloway I, McIntyre N, Reynolds B, Wheater, HS. 2014. The Impact of rural land management changes on soil hydraulic properties and runoff processes: results from experimental plots in upland UK. Hydrological Processes 28: 2617-2629.

This article is protected by copyright. All rights reserved. 
Messing I, Alriksson A, Johansson W. 1997. Soil physical properties of afforested and arable land. Soil Use and Management. 13 (4): 209-217.

Newman BD, Bradford PW, Archer SR, Breshears DD, Dahm CN, Duffy CJ, McDowell NG, Phillips FM, Scalon BR, Vivoni EN. 2006. Ecohydrology of water-limited environments: A scientific vision. Water Resources Research. 42 W06302, doi:10.1029/2005WR004141.

Nimmo JR. 2004. Porosity and Pore Size Distribution, in Hillel, D., ed. Encyclopedia of Soils in the Environment. London, Elsevier. 3, 295-303.

Nisbet, T.R., Silgram, M., Shah, N., Morrow, K. and Broadmeadow, S. (2011) Woodland for water: woodland measures for meeting WFD objectives. Forest Research Monograph, 4, Forest Research, Surrey (156pp).

Nuttle WK. 2002. Is ecohydrology one idea or many? Hydrological Sciences. 47(5):805-807. DOI: 10.1080/02626660209492983.

Ohser J, Mücklich F. 2000. Analysis and spatial images. In: Statistical Analysis of Microstructures in Material Science, Barnett, V. (ed.), 109-114. John Wiley \& Sons, New York

Osuji GE, Okon MA, Chukwuma MC, Nwarie II. 2010, Infiltration characteristics of soil under selected land use practices in Owerri, Southeastern Nigeria: World Journal of Agricultural Sciences. 6 (3): 4.

Otsu N. 1979. A threshold selection method from gray-level histograms. IEEE Transactions on Systems Management \& Cybernetics, 9: 62-66.

Ray D, Nicoll BC. 1998. The effect of soil water-table depoth on root-plate development and stability of Sitka spruce. Forestry 71(2): 169-182.

Reynolds WD, Elrick DE, Topp GC. 1983. A re-examination of the constant head well permeameter method for measuring saturated hydraulic conductivity above the water table: Soil Science. 136(4): 250-268.

Rodriguez-Iturbe I. 2000. Ecohydrology: A hydrologic perspective of climate-soil-vegetation dynamics. 36(1): 3-9. Water Resources Research. 36(1):3-9. 
Rodriguez-Iturbe I, D’Odorico P, Laio F, Ridolfi L, Tamea S. 2007 Challenges in humid land ecohydrology: Interactions of water table and unsaturateds zone with climate, soil and vegetation. Water Resources Research. 43, W09301. doi:10.1029/2007WR006073.

Rowell DL. 1994. Soil science: methods and applications. Longman Scientific and Technical: Harlow. 350.

Schwärzel K, Renger M, Saurbrey R, Wessolek G. 2002. Soil physical characteristics of peat soils. Journal of Plant Nutrition and Soil Science, 165: 475-486.

Schwärzel K, Ebermann S, Schalling N. 2012. Evidence of double-funneling effect of beech trees by visualization of flow pathways using dye tracer. Journal of Hydrology 470 (1): 184-192.

Schwinning, S. 2010. Ecohydrology bearings- Invited commentary. The ecohydrology of roots in rocks. Ecohydrology 3: 238-245.

Sobieraj JA, Elsenbeer H, Cameron G. 2004. Scale dependency in spatial patterns of saturated hydraulic conductivity. Catena 55: 49-77.

Steven HA, and Carlisle, A. 1959. The Native Pinewoods of Scotland. Oliver \& Boyd, Edinburgh, UK.

Talsma T, Hallam PM. 1980, Hydraulic conductivity measurement of forest catchments. Australian Journal of Soil Research, 18 (2): 139-148.

Taylor M, Mulholland M, Thornburrow D. 2008. Infiltration characteristics of soils under forestry and agriculture in the Upper Waikato Catchment. Environment Waikato Technical Report 2009/18. Environment Waikato, Regional Office, New Zealand. ISSN: 1177-9284.

Thomas H, Nisbet TR. 2006. An assessment of the impact of floodplain woodland on flood flows. Water and Environment Journal. 21 (2): 114-126.

Thompson SE, Harman CJ, Heine P, Katul GG. 2010. Vegetation-infiltration relationships across climatic and soil type gradients. Journal of Geophysical Research. 115, G02023, doi:10.1029/2009JG001134

Zhang I, Dawes, WR. And Walker, GR. 2001. Response of mean annual evapotranspiration to vegetation changes at catchment scale. Water Resources Research. 37 (3) 701-708. 
Zimmermann B, Elsenbeer H. 2008. Spatial and temporal variability of soil saturated hydraulic conductivity in gradients of disturbance. Journal of Hydrology. 361 (1-2): 78-95.

Zou C, Turton DJ, Will RE, Engle DM, Fuhlendorf SD. 2013. Alteration of hydrological porocesses and streamflow with juniper (Juniperus viginiana) encroachment in a mesic grassland catchment. Hydrological Processes DOI: 10.1002/hyp.10102.
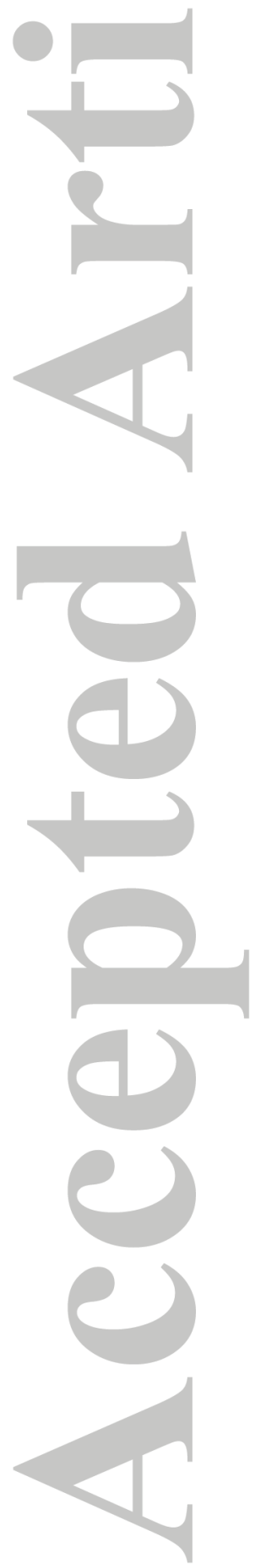

This article is protected by copyright. All rights reserved. 
Table 1) Summary of site characteristics. *Diamicton: sand or coarse sediment suspended in a mud matrix

\begin{tabular}{|c|c|c|c|c|}
\hline Site area & Land cover & Soil type & $\begin{array}{l}\text { Superficial } \\
\text { geology }\end{array}$ & Bedrock \\
\hline $\begin{array}{l}\text { 'Grass } \\
\text { (Fig 3 }\end{array}$ & $\begin{array}{l}\text { Grassland area grazed } \\
\text { by cattle }\end{array}$ & $\begin{array}{l}\text { Peaty podzols } \\
\text { with peat and } \\
\text { peaty gleys: } \\
\text { humus iron } \\
\text { podzols }\end{array}$ & $\begin{array}{l}\text { Glacial fluvial } \\
\text { deposits: sand, } \\
\text { gravel and } \\
\text { boulders }\end{array}$ & $\begin{array}{l}\text { Micaceouspsammite } \\
\text { (sandstone) }\end{array}$ \\
\hline $\begin{array}{l}6 \text { year old } \\
\text { Scots pine } \\
\text { (Fig 3b) }\end{array}$ & $\begin{array}{l}\text { Six year old Scots } \\
\text { pine plantation. Pines } \\
\text { are planted in rows } \\
\text { between drainage } \\
\text { lines. Silver birch } \\
\text { present in patches } \\
\text { seeded by natural } \\
\text { regeneration } \\
\text { processes }\end{array}$ & $\begin{array}{l}\text { Peaty podzols } \\
\text { with peat and } \\
\text { peaty gleys: } \\
\text { humus iron } \\
\text { podzols }\end{array}$ & $\begin{array}{l}\text { Hummocky } \\
\text { glacial deposits: } \\
\text { *diamicton, } \\
\text { sand and gravel }\end{array}$ & $\begin{array}{l}\text { Micaceouspsammite } \\
\text { (sandstone) }\end{array}$ \\
\hline $\begin{array}{l}48 \text { year old } \\
\text { Scots pine } \\
\text { plantation } \\
\text { (Fig 3c) }\end{array}$ & $\begin{array}{l}\text { Forty-nine year old } \\
\text { Scots pine plantation } \\
\text { planted in lines which } \\
\text { have been thinned. }\end{array}$ & $\begin{array}{l}\text { Peaty podzol } \\
\text { with humus- } \\
\text { iron podzols, } \\
\text { peaty gleys } \\
\text { with rankers }\end{array}$ & $\begin{array}{l}\text { Hummocky } \\
\text { glacial deposits: } \\
\text { *diamicton, } \\
\text { sand and gravel }\end{array}$ & $\begin{array}{l}\text { Micaceouspsammite } \\
\text { (sandstone) }\end{array}$ \\
\hline $\begin{array}{l}\text { 'Old Tree } \\
\text { (Fig 1d) }\end{array}$ & $\begin{array}{l}\text { Remnant } 300 \text { year old } \\
\text { individual Scots pine } \\
\text { trees. The } \\
\text { surrounding Scots } \\
\text { pine plantation was } \\
\text { cut down seven years } \\
\text { ago, so that old } \\
\text { remnant trees remain. } \\
\text { Scots pine is being } \\
\text { replaced by natural } \\
\text { regeneration of } \\
\text { juniper, heather and } \\
\text { bilberry. }\end{array}$ & $\begin{array}{l}\text { Peaty podzols } \\
\text { with peat and } \\
\text { peaty gleys: } \\
\text { humus iron } \\
\text { podzols }\end{array}$ & $\begin{array}{l}\text { Hummocky } \\
\text { glacial deposits: } \\
\text { *diamicton, } \\
\text { sand and gravel }\end{array}$ & $\begin{array}{l}\text { Micaceouspsammite } \\
\text { (sandstone) }\end{array}$ \\
\hline $\begin{array}{l}\text { 'Ancient } \\
\text { Forest' } \\
\text { (Fig. 1e) }\end{array}$ & $\begin{array}{l}\text { Within narrow valley } \\
\text { in a remnant } 4000 \\
\text { year old Caledonian } \\
\text { Forest. }\end{array}$ & $\begin{array}{l}\text { Peaty podzols } \\
\text { with peat: } \\
\text { peaty gleys } \\
\text { with humus- } \\
\text { iron podzols }\end{array}$ & $\begin{array}{l}\text { Biotite granite } \\
\text { outcrop, } \\
\text { localized } \\
\text { alluvial } \\
\text { deposits }\end{array}$ & Biotite granite \\
\hline
\end{tabular}

This article is protected by copyright. All rights reserved. 
Table 2) Soil characteristics for all sites at three different soil depths. Values in brackets are standard errors between three replicate soil pits. *Excludes gravel.

\begin{tabular}{|c|c|c|c|c|c|c|}
\hline Site & Soil depth & Grassland & $6 y r$ & $48 \mathrm{yr}$ & $\begin{array}{l}\text { Old } \\
\text { Trees }\end{array}$ & $\begin{array}{l}\text { Ancient } \\
\text { forest }\end{array}$ \\
\hline $\begin{array}{l}\text { Average dry } \\
\text { bulk density } \\
\left(\mathrm{g} / \mathrm{cm}^{3}\right)^{*}\end{array}$ & $\begin{array}{l}0.06 \text { to } \\
0.10 \mathrm{~m} \\
0.16 \text { to } \\
0.20 \mathrm{~m} \\
0.26 \text { to } \\
0.40 \mathrm{~m}\end{array}$ & $\begin{array}{l}0.71 \\
( \pm 0.11) \\
0.91 \\
( \pm 0.13) \\
1.20 \\
( \pm 0.16)\end{array}$ & $\begin{array}{l}0.14 \\
( \pm 0.01) \\
0.13 \\
( \pm 0.02) \\
0.12 \\
( \pm 0.01)\end{array}$ & $\begin{array}{l}0.41 \\
( \pm 0.08) \\
0.94 \\
( \pm 0.05) \\
0.83 \\
( \pm 0.16)\end{array}$ & $\begin{array}{l}0.45 \\
( \pm 0.16) \\
0.63 \\
( \pm 0.15) \\
0.99 \\
( \pm 0.14)\end{array}$ & $\begin{array}{l}0.11 \\
( \pm 0.02) \\
1.09 \\
( \pm 0.09) \\
0.57 \\
( \pm 0.23)\end{array}$ \\
\hline $\begin{array}{l}\text { Average loss } \\
\text { on ignition } \\
\text { (g/100 dry } \\
\text { soil) }\end{array}$ & $\begin{array}{l}0.06 \text { to } \\
0.10 \mathrm{~m} \\
0.16 \text { to } \\
0.20 \mathrm{~m} \\
0.26 \text { to } \\
0.40 \mathrm{~m}\end{array}$ & $\begin{array}{l}17.08 \\
( \pm 3.39) \\
13.56 \\
( \pm 3.80) \\
7.39 \\
( \pm 2.40)\end{array}$ & $\begin{array}{l}93.68 \\
( \pm 1.74) \\
91.60 \\
( \pm 2.44) \\
93.20 \\
( \pm 0.31)\end{array}$ & $\begin{array}{l}46.33 \\
( \pm 14.5) \\
10.46 \\
( \pm 1.96) \\
17.66 \\
( \pm 6.22)\end{array}$ & $\begin{array}{l}36.57 \\
( \pm 13.0) \\
22.80 \\
( \pm 6.33) \\
13.11 \\
( \pm 3.15)\end{array}$ & $\begin{array}{l}93.79 \\
( \pm 1.43) \\
4.11 \\
( \pm 1.43) \\
51.7 \\
( \pm 24.8)\end{array}$ \\
\hline $\begin{array}{l}\text { Median } \\
\text { saturated } \\
\text { volumetric } \\
\text { water content } \\
(\mathrm{v} / \mathrm{v})\end{array}$ & $\begin{array}{l}0.06 \text { to } \\
0.10 \mathrm{~m} \\
0.16 \text { to } \\
0.20 \mathrm{~m} \\
0.26 \text { to } \\
0.40 \mathrm{~m}\end{array}$ & $\begin{array}{l}0.69 \\
( \pm 0.04) \\
0.63 \\
( \pm 0.03) \\
0.54 \\
( \pm 0.06)\end{array}$ & $\begin{array}{l}0.89 \\
( \pm 0.03) \\
0.87 \\
( \pm 0.04) \\
0.96 \\
( \pm 0.02)\end{array}$ & $\begin{array}{l}0.84 \\
( \pm 0.07) \\
0.59 \\
( \pm 0.06) \\
0.62 \\
( \pm 0.07)\end{array}$ & $\begin{array}{l}0.73 \\
( \pm 0.07) \\
0.68 \\
( \pm 0.04) \\
0.61 \\
( \pm 0.03)\end{array}$ & $\begin{array}{l}0.83 \\
( \pm 0.04) \\
0.58 \\
( \pm 0.06) \\
0.81 \\
( \pm 0.10)\end{array}$ \\
\hline $\begin{array}{l}\text { Soil volume } \\
\text { fraction loss } \\
\text { (v/v) } \\
\text { (shrinkage) } \\
\text { from saturated } \\
\text { to } 250 \mathrm{kPa} \\
\text { suction. }\end{array}$ & $\begin{array}{l}0.06 \text { to } \\
0.10 \mathrm{~m} \\
0.16 \text { to } \\
0.20 \mathrm{~m} \\
0.26 \text { to } \\
0.40 \mathrm{~m}\end{array}$ & $\begin{array}{l}0.08 \\
( \pm 0.01) \\
0.03 \\
( \pm 0.03) \\
0.00 \\
( \pm 0.00)\end{array}$ & $\begin{array}{l}0.34 \\
( \pm 0.10) \\
0.42 \\
( \pm 0.02) \\
0.46 \\
( \pm 0.04)\end{array}$ & $\begin{array}{l}0.06 \\
( \pm 0.02) \\
0.37 \\
( \pm 0.37) \\
0.00 \\
( \pm 0.00)\end{array}$ & $\begin{array}{l}0.00 \\
( \pm 0.00) \\
0.02 \\
( \pm 0.02) \\
0.00 \\
( \pm 0.00)\end{array}$ & $\begin{array}{l}0.04 \\
( \pm 0.02) \\
0.02 \\
( \pm 0.02) \\
0.03 \\
( \pm 0.03)\end{array}$ \\
\hline $\begin{array}{l}\text { Minimum, } \\
\text { median and } \\
\text { maximum } \\
\text { field hydraulic } \\
\text { conductivity } \\
\left.(\mathrm{mm} \mathrm{hr})^{-1}\right)\end{array}$ & $\begin{array}{l}0.04-0.15 \\
0.04-0.15 \\
0.04-0.15 \\
0.15-0.25 \\
0.15-0.25 \\
0.15-0.25\end{array}$ & $\begin{array}{l}1.8 \\
7.1 \\
13.1 \\
1.3 \\
3.9 \\
8.2\end{array}$ & $\begin{array}{l}0.2 \\
2.3 \\
5.9 \\
<0.001 \\
0.19 \\
10.7\end{array}$ & $\begin{array}{l}16.5 \\
33.8 \\
236.6 \\
1.86 \\
13.9 \\
14.8\end{array}$ & $\begin{array}{l}8.8 \\
31.2 \\
251.6 \\
2.95 \\
5.12 \\
23.0\end{array}$ & $\begin{array}{l}62 \\
224 \\
>4922 \\
12 \\
75 \\
>4922\end{array}$ \\
\hline $\begin{array}{l}\text { Average total } \\
>1 \mathrm{~mm} \\
\text { diameter roots } \\
\text { from three soil } \\
\text { pits (root } \\
\text { counts } / \mathrm{m}^{2} \text { ) }\end{array}$ & $0.15-0.25$ & $\begin{array}{l}460 \\
( \pm 62.0) \\
228 \\
( \pm 66.0) \\
140 \\
( \pm 19.8)\end{array}$ & $\begin{array}{l}273 \\
( \pm 138.1) \\
86 \\
( \pm 62.5) \\
273 \\
( \pm 220)\end{array}$ & $\begin{array}{l}457 \\
( \pm 124.9) \\
518 \\
( \pm 133.4) \\
559 \\
( \pm 239)\end{array}$ & $\begin{array}{l}714 \\
( \pm 669) \\
400 \\
( \pm 208) \\
298 \\
( \pm 104.5)\end{array}$ & $\begin{array}{l}946 \\
( \pm 281) \\
702 \\
( \pm 517) \\
911 \\
( \pm 819)\end{array}$ \\
\hline
\end{tabular}



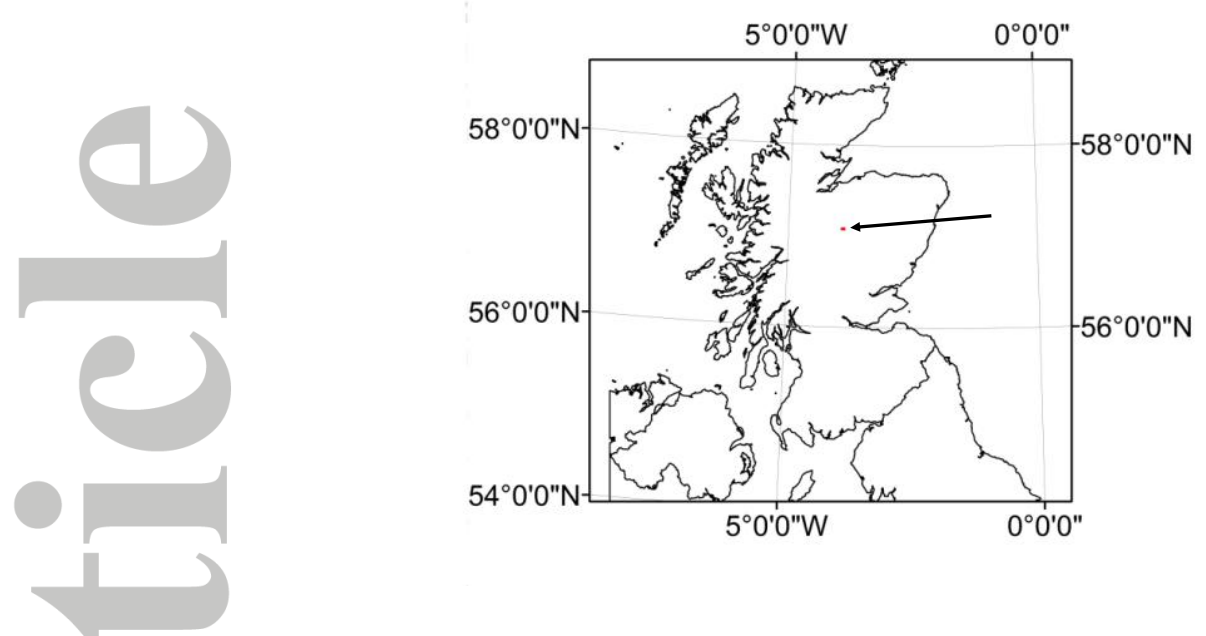

Fig. 1a) The arrow indicates the location of field area in the Cairngorm mountains, Scotland.
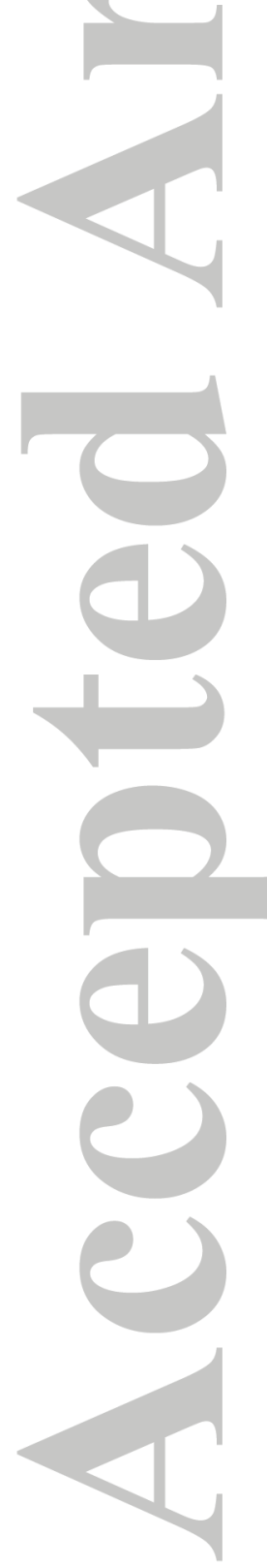

This article is protected by copyright. All rights reserved. 

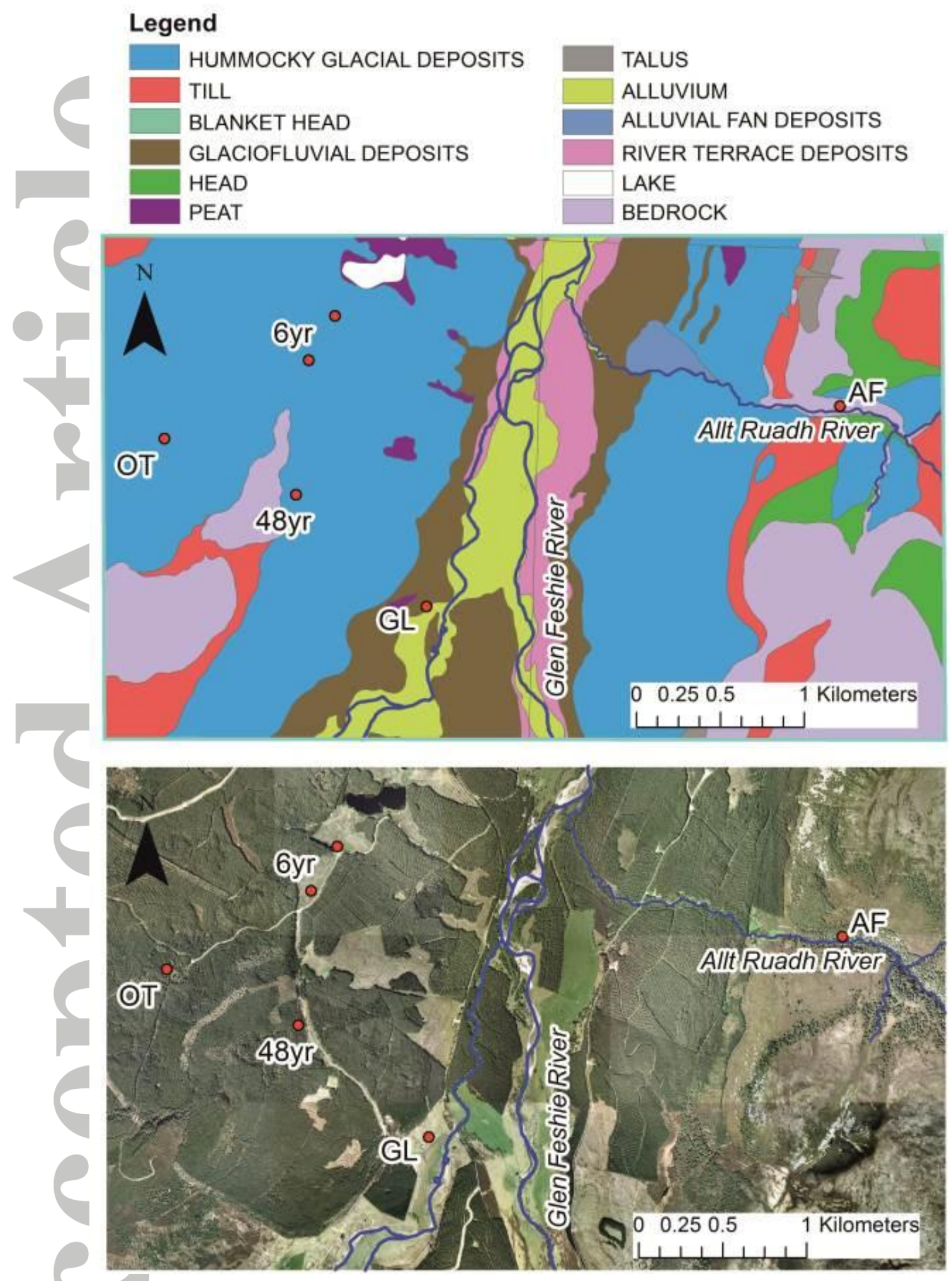

Fig. 1b) The upper map shows the superficial geology of the area and indicates the locations of the five field sites: GL: grazed grassland, 6yr: a six-year-old Scots pine plantation, 48yr: 48-year-old Scots pine plantation; OT: 'Old trees' is an area of individual 300 year old Scots pine, AF: 'Ancient Forest' a remnant Caledonian Forest. The lower map is an aerial view showing the extent of forest cover in relation to the five field sites. 


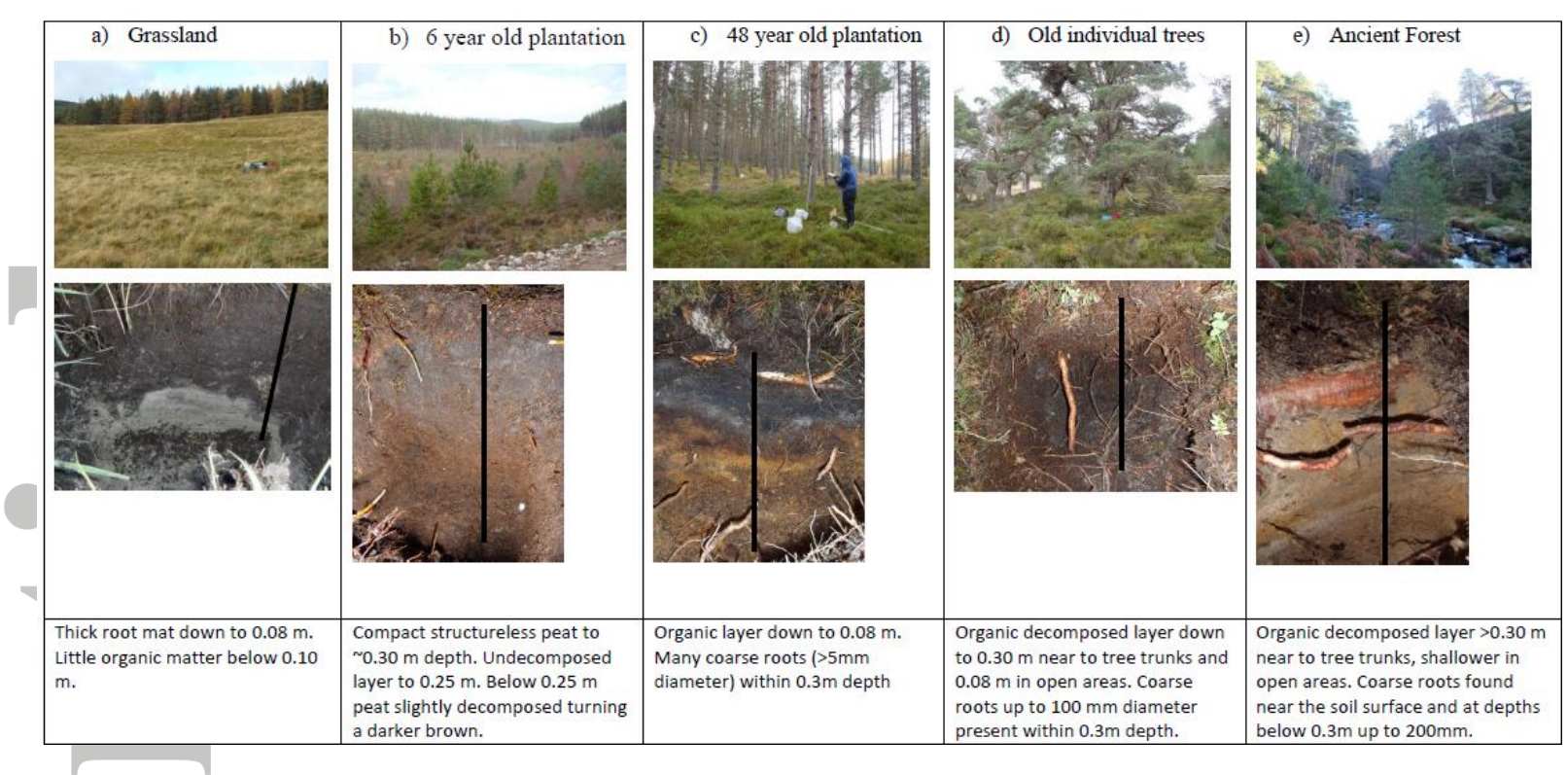

Fig. 2) The five study areas and typical soil profiles showing depths of organic layers and presence of roots for each area. The black lines in each soil profile represent $0.3 \mathrm{~m}$ scale.

This article is protected by copyright. All rights reserved. 


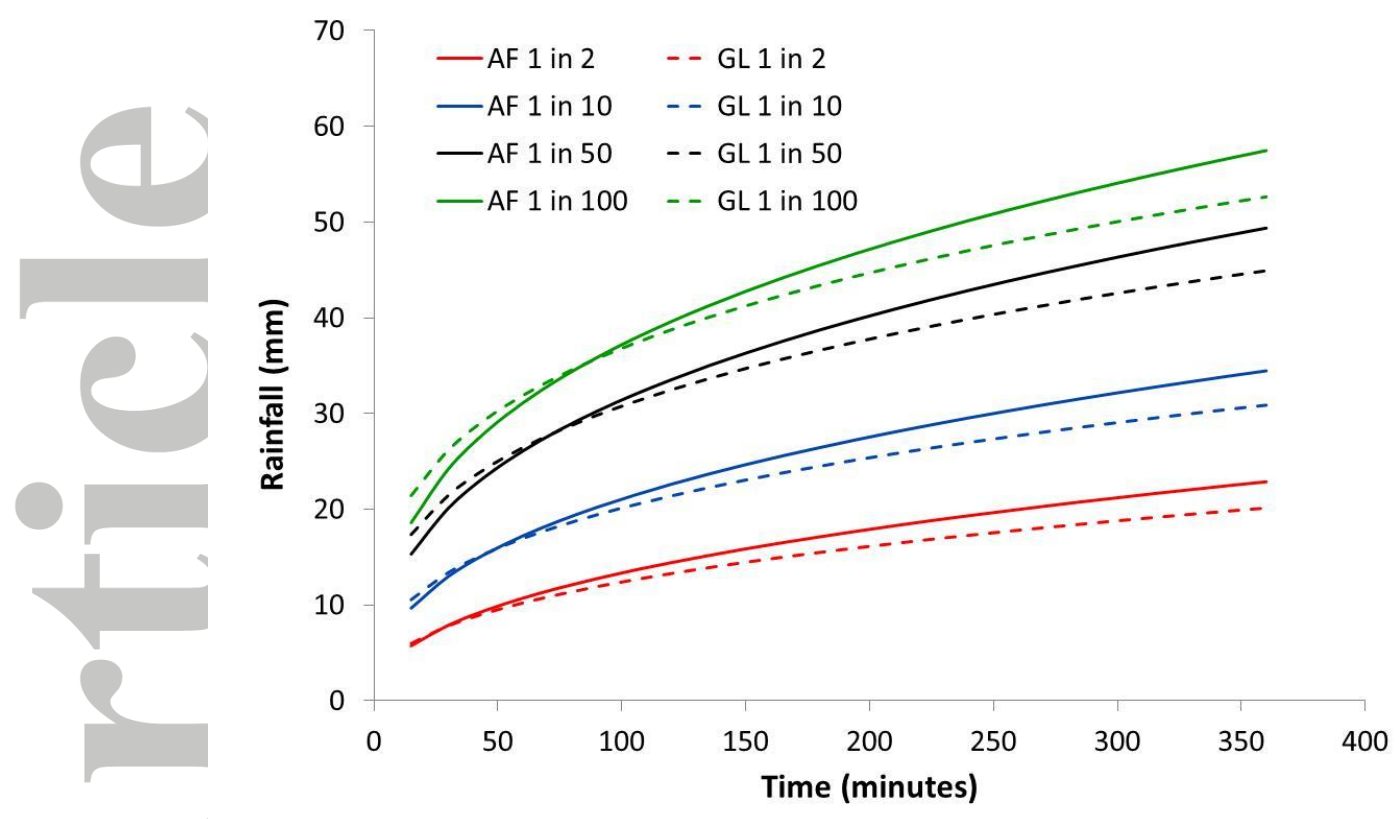

Fig. 3) Density Duration Frequency Curves modelled using the Flood Estimation Handbook Faulkner (1999), for 15 to 360 minute duration rainfall for 1 in 2, 1 in 10,1 in 50 and 1 in 100 storm events for the site area. The full lines are curves generated for the grassland, 6year-old plantation, 48-year-old plantation and Old Tree sites and the dotted curves are generated for the Ancient Forest site.

This article is protected by copyright. All rights reserved. 

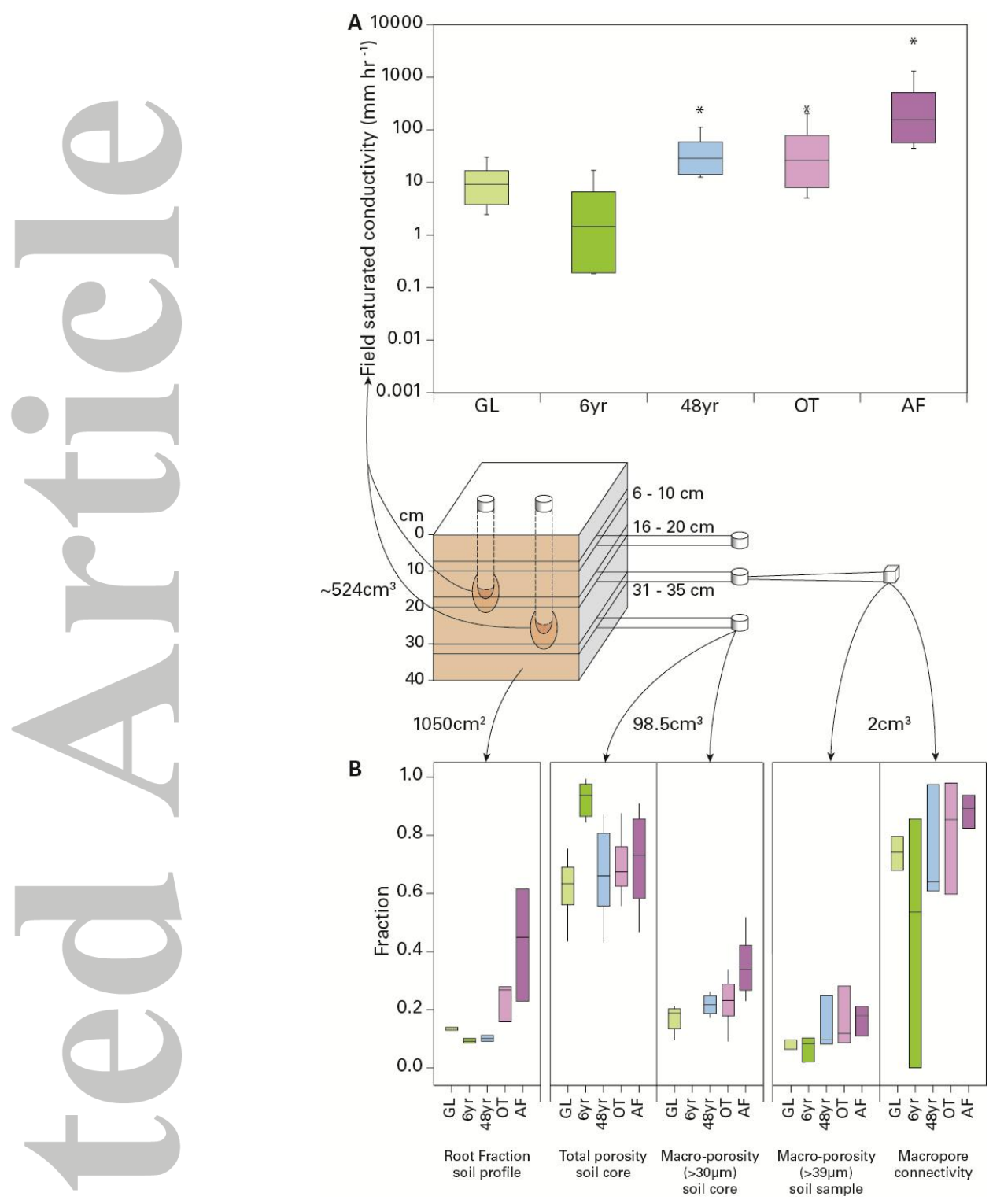

Fig. 4) A) Box plot of all $K_{f s}$ data measured at depths 0.04 to $0.15 \mathrm{~m}$ and 0.15 to $0.25 \mathrm{~m}$ for each site. B) Box plots of all data for each site: a) Fraction of roots in terms of surface area $\left(\mathrm{m}^{2}\right)$ estimated from three $1050 \mathrm{~cm}^{2}$ soil profiles, b) total porosity estimated from nine 98.5 $\mathrm{cm}^{3}$, taken at three depths $(0.06-0.10,0.16$ to 0.20 , and 0.26 to 0.40$)$ using the pressure chamber technique, c) macroporisty (>30 $\mu \mathrm{m}$ ) estimated from nine $98.5 \mathrm{~cm}^{3}$, taken at three depths $(0.06-0.10,0.16$ to 0.20 , and 0.26 to 0.40$)$ using the pressure chamber technique, $\mathrm{d})$ macroporsity $(>39 \mu \mathrm{m})$ of $2 \mathrm{~cm}^{3}$ of soil samples measured from 3D volumetric images of cores at 0.16 to $0.25 \mathrm{~m}$ using Minkowski functionals, e) connectivity of macropores (>39 $\mu \mathrm{m}$ ) within $2 \mathrm{~cm}^{3}$ of soil samples taken from cores at 0.16 to $0.25 \mathrm{~m}$ using Minkowski functionals. GL is grassland site, $6 \mathrm{yr}$ is the Scots 6 year plantation, $48 \mathrm{yr}$ is the 48 year old Scots pine plantation, OT is the individual Old Scots pines and AF is the ancient Caledonian Forest. 


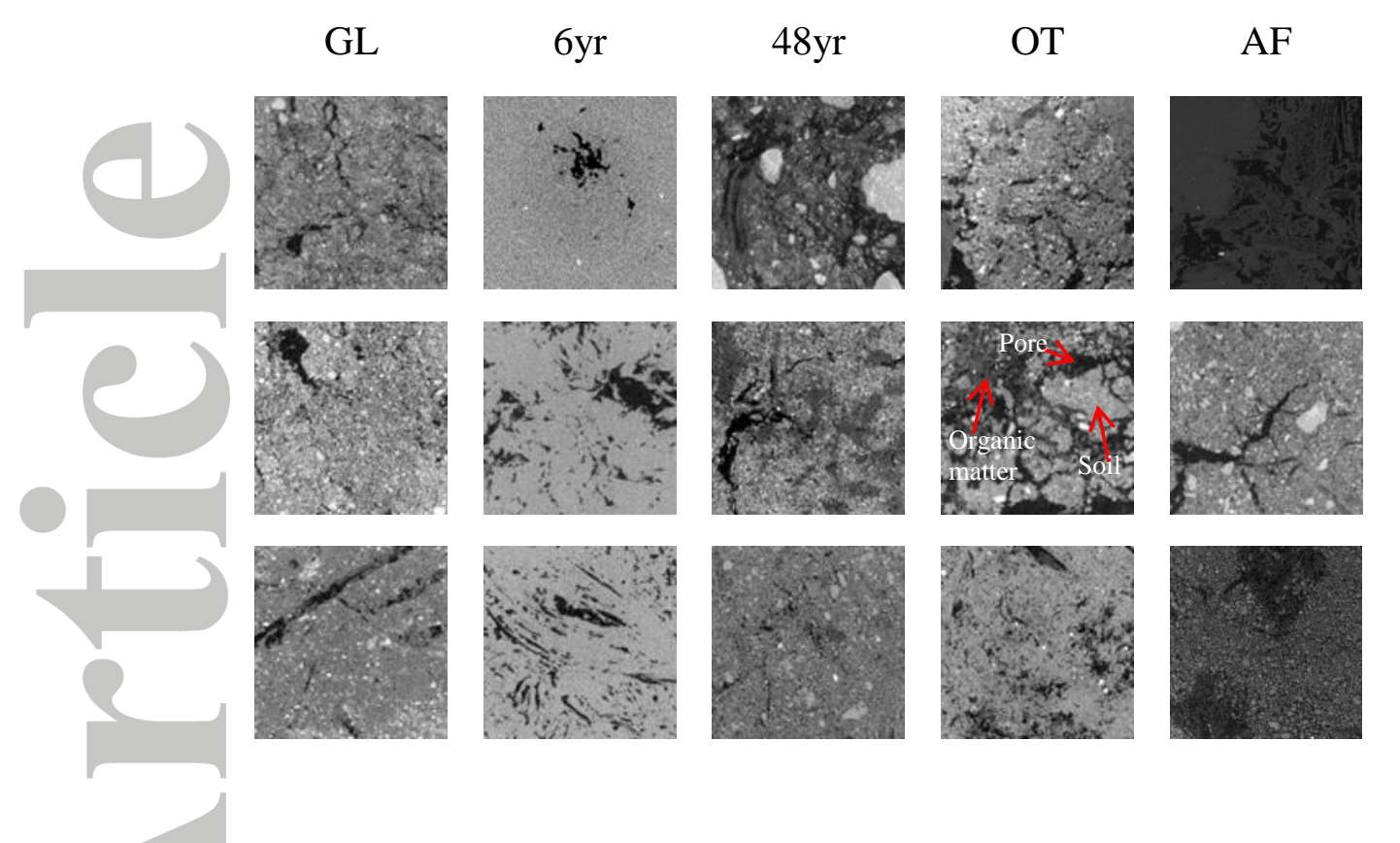

Fig 5) 2D cross sections (512 voxels x 512 voxels) of soil samples collected at $0.16-0.25 \mathrm{~m}$ soil depths at the five different sites Grassland (GL), 6 year old Scots pine (6yr), 48 year old Scots pine (48yr), 300 year individual trees (OT) and ancient forest (AF).

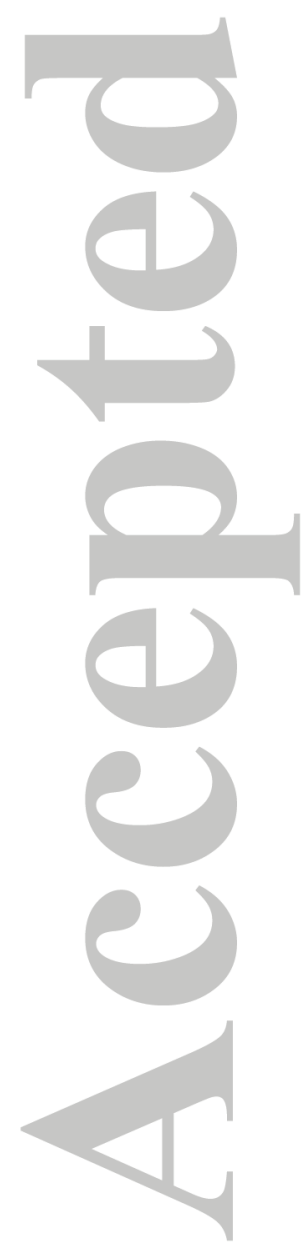

This article is protected by copyright. All rights reserved. 


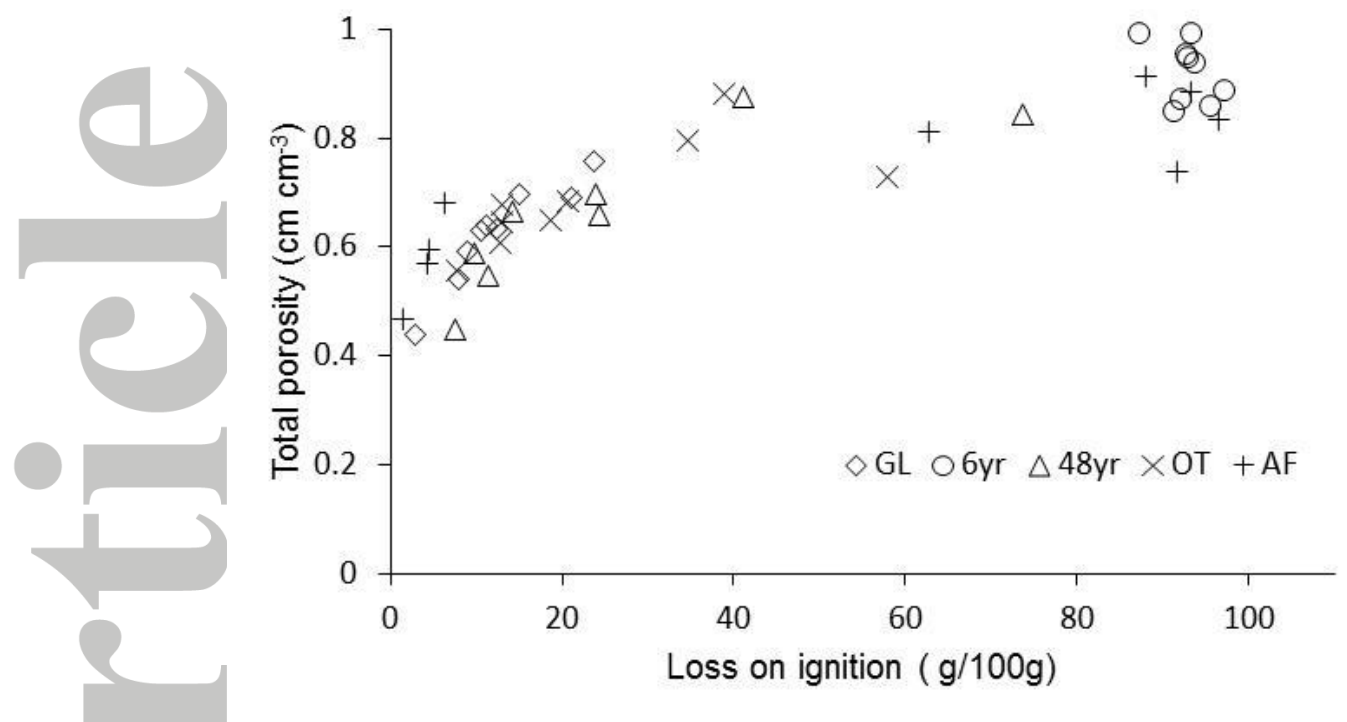

Fig. 6) The relationship between total porosity and organic matter content defined by loss on ignition. Regression line is $y=0.1203 \operatorname{In}(x)+0.3419, \mathrm{R} 2=0.8323$. GL is grassland, 6yr is the 6-year-old Scots pine plantation, 48yr is the 48-year-old Scots Pine plantation, OT is the 300 year-old individual Scots Pines and AF is the 4000 year old Ancient Forest.

This article is protected by copyright. All rights reserved. 


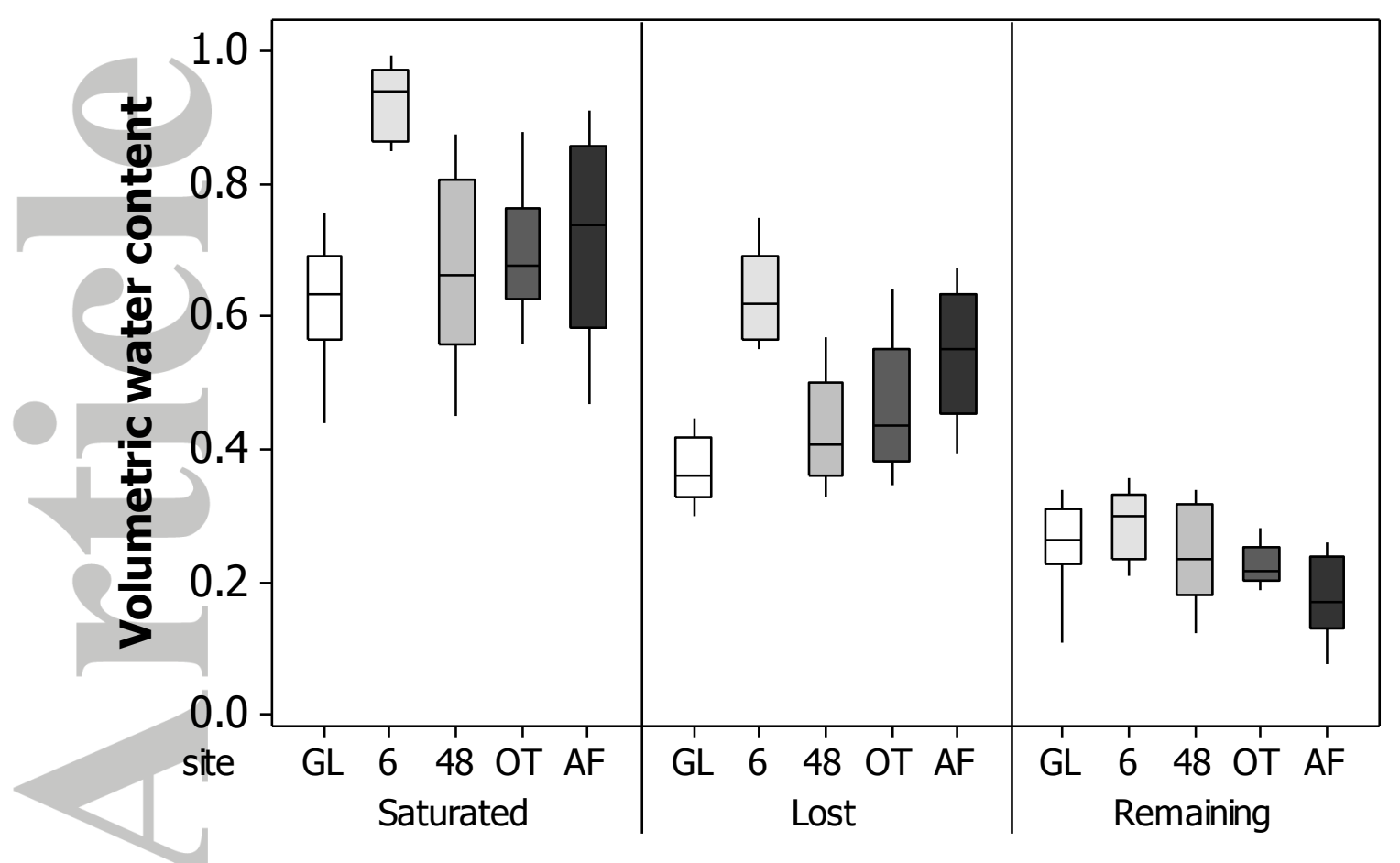

Fig. 7) The column 'Saturated' is the saturated water content for cores taken from the three pits ( 0.05 to $0.35 \mathrm{~m}$ soil depth) for each site. 'Lost' is the amount of water removed after 250 $\mathrm{kPa}$ matric potential has been applied to the cores for each site. 'Remaining' is the amount of water left in the soil cores for each site after $250 \mathrm{kPa}$ matric potential has been applied to the cores. GL is grassland, 6 is the 6 year-old Scots pine plantation, 48 is the 48 year-old Scots Pine plantation, OF is the 300 year-old individual Scots Pine and AF is the 4000 year old Ancient Forest. 


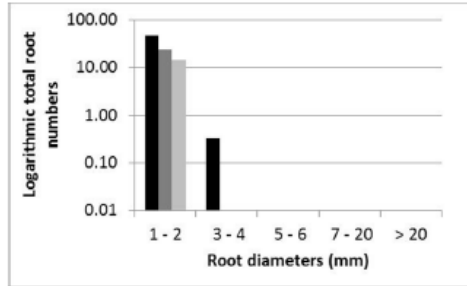

A) GL

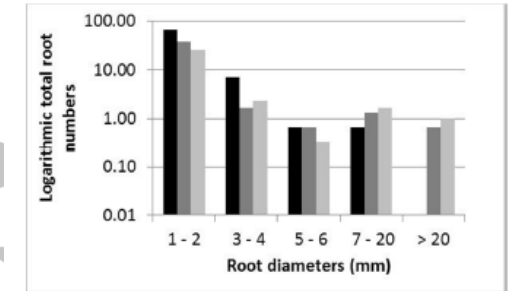

D) OT

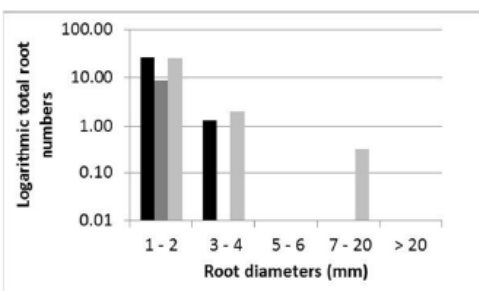

B) $6 \mathrm{yr}$

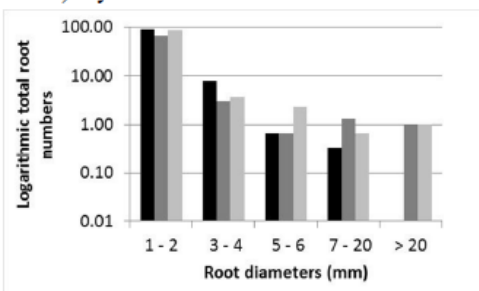

E) $\mathrm{AF}$

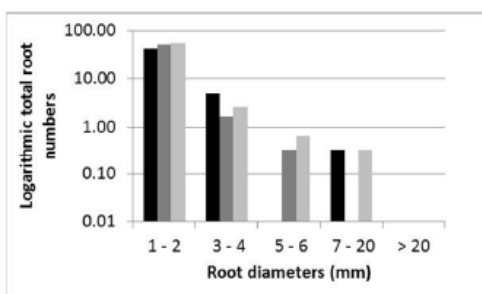

C) $48 \mathrm{yr}$

Fig 8) Average total root numbers (logarithmic scale) for three different soil depths and root diameters for A) Ancient Forest (AF), B) 'Old Trees' (OT), individual 300 year old trees, C) $48 \mathrm{yr}$ is 48 year old Scots Pine plantation, D) 6yr is 6 year old Scots plantation and E) Grassland. The black column is soil depth 0.05 to $0.15 \mathrm{~m}$, dark grey column is soil depth 0.15 to $0.25 \mathrm{~m}$ and light grey is soil depth 0.25 to 0.35 . F) Average proportions of root area, stones/rock areas and soil matrix. Values for each component were averaged from three soil pits taken from each study area.

This article is protected by copyright. All rights reserved. 


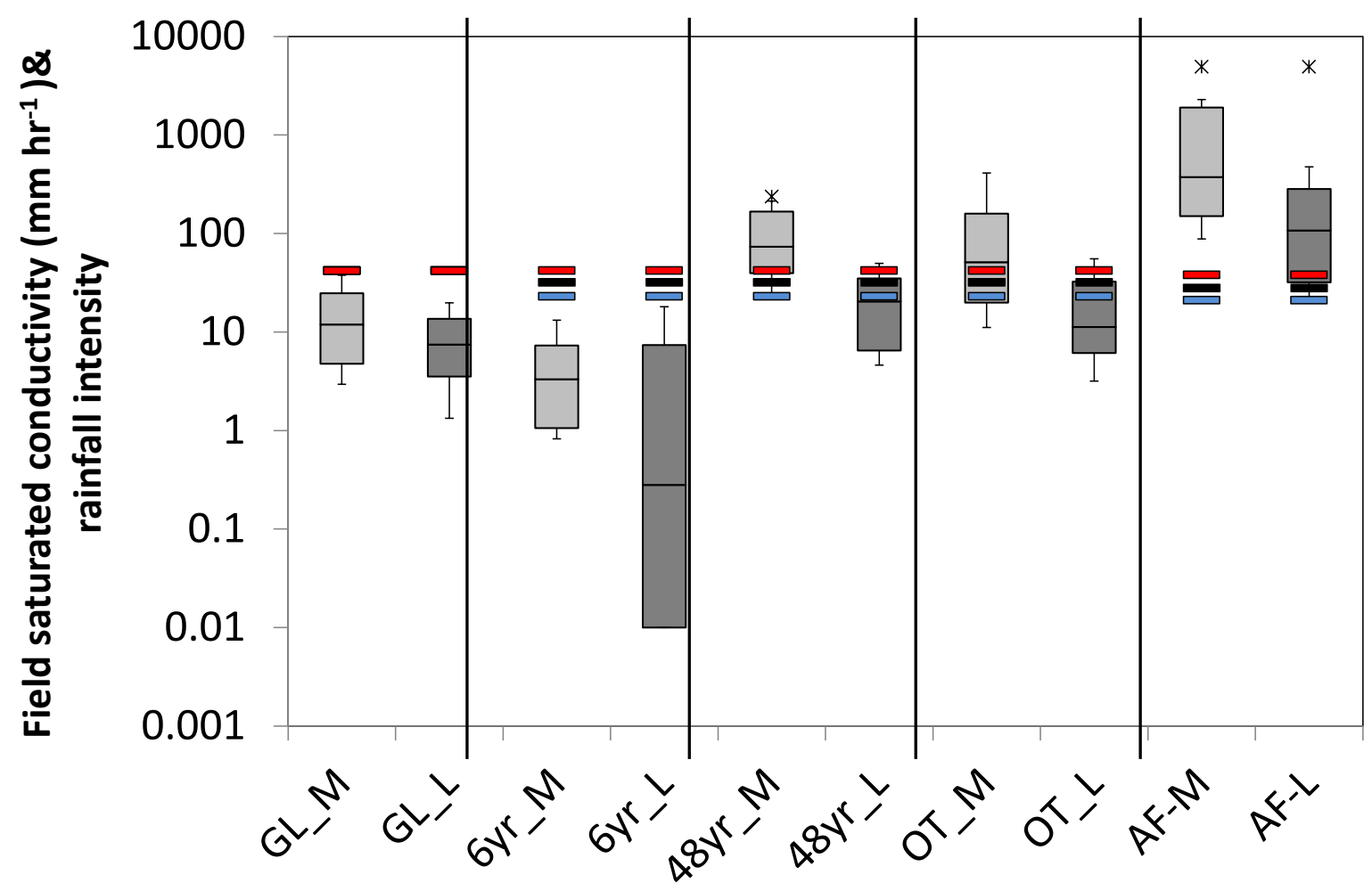

Fig. 9) Box plots of measured field saturated hydraulic conductivity $\left(K_{f s}\right)$._M denotes 0.04 to $0.15 \mathrm{~m}$ soil depth and _L denotes 0.15 to $0.25 \mathrm{~m}$ soil depth. GL is grassland area grazed by cattle, 6yr is the 6 year-old Scots pine plantation, 48yr is the 48 year-old Scots Pine plantation, OT is the 300 year-old individual Scots Pine and AF is the 4000 year old Ancient Forest. The thick red lines show the limits of modelled 1 in 10 year 15 minute maximum rainfall $\left(I_{\max 15}\right)$. The double lines for tree covered sites show the 1 in $10 I_{\max 15}$ reduced by $25 \%$ rainfall interception (upper black line) and $45 \%$ rainfall interception (lower blue line). If the box plots are below these lines, overland flow will occur at these sites for 1 in 10 year $I_{\text {max } 15}$ events. 


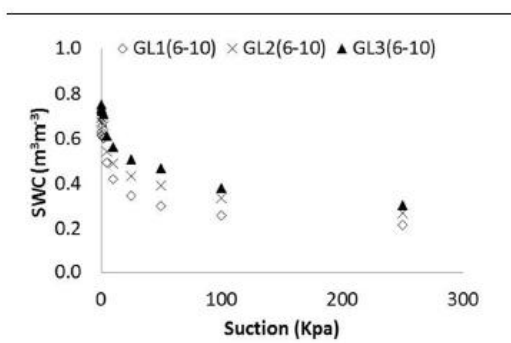

GL (Upper soil layer)

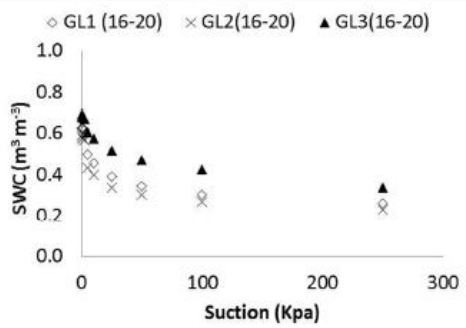

GL (Mid soil layer)

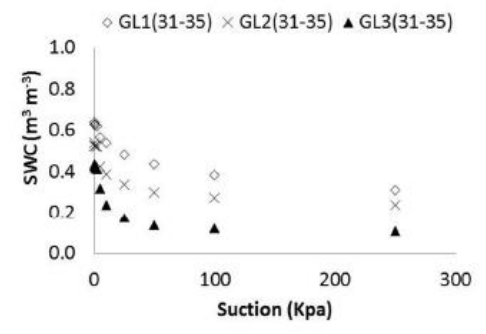

GL (Lower soil layer)
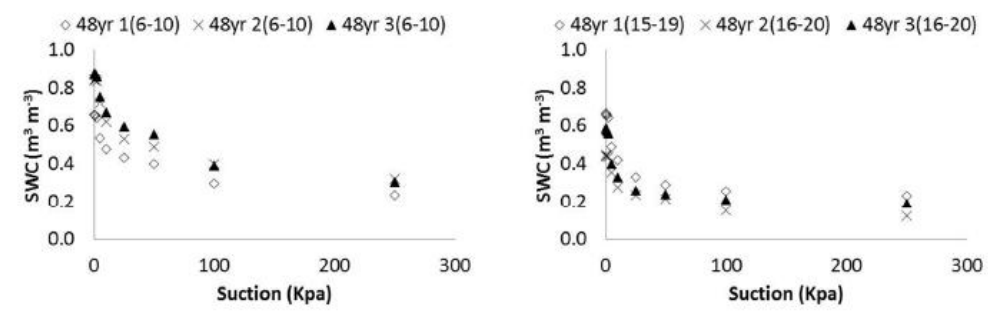

48yr (Upper soil layer) 48yr (Mid soil layer)

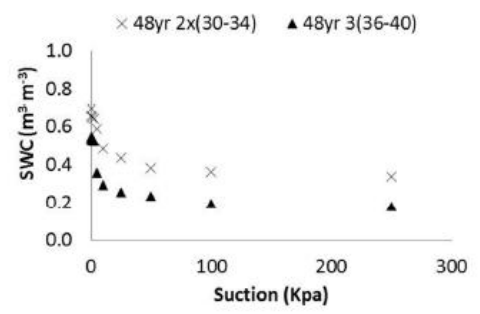

48yr (Lower soil layer)
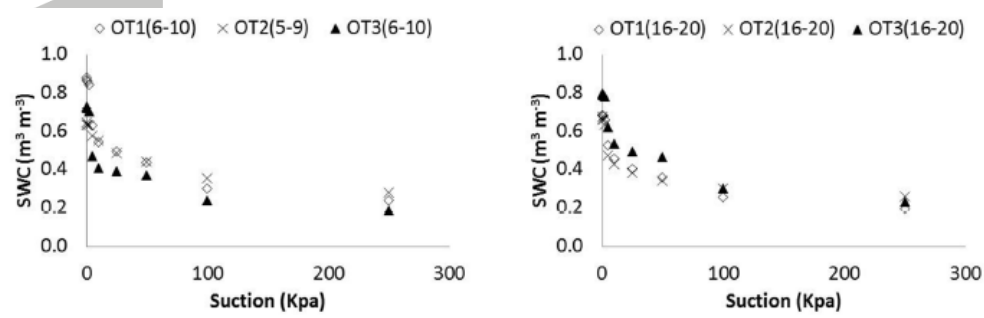

OT (Upper soil layer) OT (Mid soil layer)

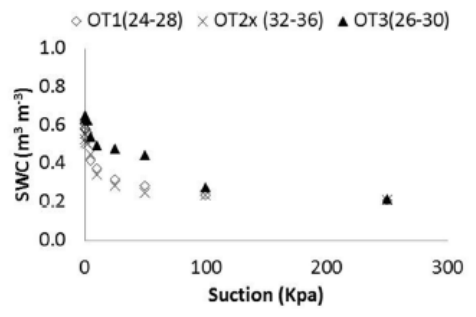

OT (Lower soil layer)
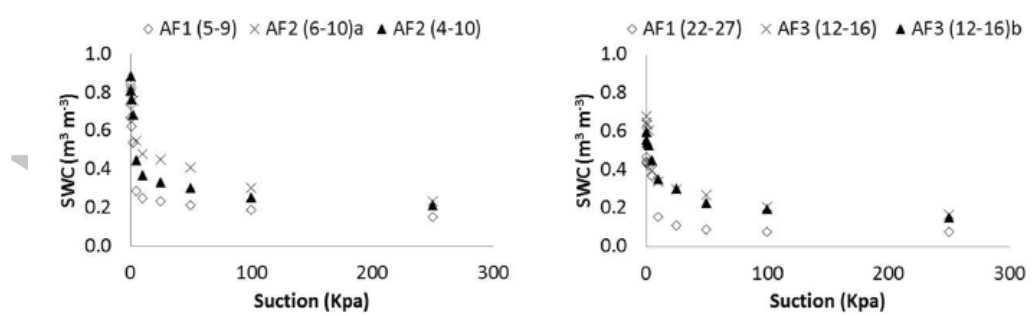

AF (Upper soil layer)

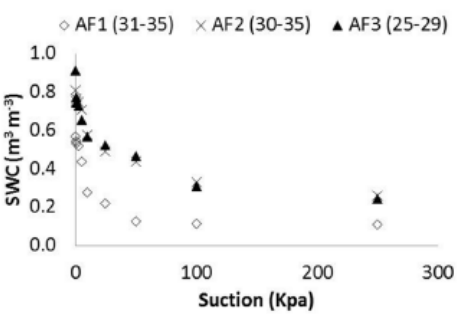

AF (Lower soil layer)

Fig. 10) Plotted raw values of water retention curves for Grassland (GL), 48 year old Scots pine plantation, (48yr), 300 year old individual Scots pine trees (OT) and Ancient Caledonian Forest (AF). The values in brackets for each legend are the depths of each core in $\mathrm{cm} .6$ year old Scots pine plantation are not shown because of problems of soil shrinkage. SWC is soil water content.

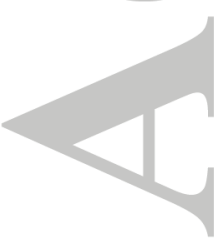

This article is protected by copyright. All rights reserved. 